\title{
Exogenous 2-(3,4-Dichlorophenoxy) triethylamine alleviates salinity stress in maize by enhancing photosynthetic capacity, improving water status and maintaining $\mathrm{K}^{+} / \mathrm{Na}^{+}$homeostasis
}

Lijie Li ${ }^{1,2}$, Wanrong Gu ${ }^{1 *}$ (D) Liguo Zhang ${ }^{3}$, Congfeng Li $i^{4}$, Xichang Chen ${ }^{3}$, Chunrong Qian ${ }^{3}$, Zhenhua Wang ${ }^{1}$, Wenhua $\mathrm{Li}^{3}$, Shiyu Zuo and Shi Wei ${ }^{1}$

\begin{abstract}
Background: Soil salinity restricts plant growth and productivity. 2-(3,4-dichlorophenoxy) triethylamine (DCPTA) can alleviate salinity stress in plants. However, the mechanism of DCPTA-mediated salinity tolerance has not been fully clarified. We aimed to investigate its role in enhancing photosynthetic capacity, improving water status, maintaining $\mathrm{K}^{+} / \mathrm{Na}^{+}$homeostasis and alleviating salinity stress in maize (Zea mays L.).

Results: In present study, maize seedlings were grown in nutrient solutions with a combination of $\mathrm{NaCl}(0,150$ $\mathrm{mM})$ and DCPTA $(0,20,100$, and $400 \mu \mathrm{M})$. And photosynthesis, water status, ion homeostasis and the expression of genes involved in ion uptake and transport were evaluated in the maize seedlings. The results demonstrated that DCPTA alleviated the growth inhibition of maize seedlings exposed to salinity stress by increasing the net photosynthetic rate $\left(P_{n}\right)$ and the quantum efficiency of photosystem II (PSII) photochemistry. DCPTA improved the root hydraulic conductivity, which help maintained the water status. A relatively high $\mathrm{K}^{+}$concentration but a relatively low $\mathrm{Na}^{+}$concentration and the $\mathrm{Na}^{+} / \mathrm{K}^{+}$ratio were observed in the presence of DCPTA under salinity stress. Additionally, DCPTA altered the expression of four genes (ZmSOS1, ZmHKT1, ZmNHX1 and ZmSKOR) that encode membrane transport proteins responsible for $\mathrm{K}^{+} / \mathrm{Na}^{+}$homeostasis.
\end{abstract}

Conclusions: DCPTA improved the salinity tolerance of maize may be associated with enhanced photosynthetic capacity, maintenance of water status and altered expression of genes involved in ion uptake and transport.

Keywords: DCPTA, Salinity stress, Photosynthesis, Water status, Ion homeostasis

\footnotetext{
* Correspondence: wanronggu@163.com

${ }^{1}$ College of Agriculture, Northeast Agricultural University, Harbin 150030, P. R.

China

Full list of author information is available at the end of the article
}

(C) The Author(s). 2020 Open Access This article is licensed under a Creative Commons Attribution 4.0 International License, which permits use, sharing, adaptation, distribution and reproduction in any medium or format, as long as you give appropriate credit to the original author(s) and the source, provide a link to the Creative Commons licence, and indicate if changes were made. The images or other third party material in this article are included in the article's Creative Commons licence, unless indicated otherwise in a credit line to the material. If material is not included in the article's Creative Commons licence and your intended use is not permitted by statutory regulation or exceeds the permitted use, you will need to obtain permission directly from the copyright holder. To view a copy of this licence, visit http://creativecommons.org/licenses/by/4.0/ The Creative Commons Public Domain Dedication waiver (http://creativecommons.org/publicdomain/zero/1.0/) applies to the data made available in this article, unless otherwise stated in a credit line to the data. 


\section{Background}

Soil salinization is one of the most severe adverse environmental factors limiting agricultural development $[1,2]$. Approximately 830 million hectares (ha) of land (approximately $20 \%$ of the cultivated land area worldwide) is impacted by soil salinization [3-5], and an annual worldwide loss of US\$12-27.3 billion occurs due to lost crop production [6]. It is expected that in 2050, the global population will surpass 9.1 billion, necessitating another $70 \%$ increase in food production to ensure food security [7]. Soil salinization will be the major obstacle in the way of achieving this goal [8].

Soil salinity initiates complex responses to inhibit plant growth and physiological processes [4, 9]. Initially soil salinity is known to represses plant growth in the form of osmotic stress due to high salt concentration in root zones, which is then followed by ion deficiency or toxicity due to acytosol over-accumulation of $\mathrm{Na}^{+}$and $\mathrm{Cl}^{-}[10,11]$. Osmotic stress impairs cell water relations, inhibits cell expansion and division, and reduces stomatal aperture and transpiration [12, 13]. Stomatal closure limits the diffusion of atmospheric $\mathrm{CO}_{2}$ to the site of carboxylation and causes the stomatal limitation of photosynthesis, consequently decreasing growth rates [13]. Salinity-induced decreases in photosynthetic efficiency are often associated with the inhibition of photosystem II (PSII), which plays a central role in light energy conversion and electron transport [14]. Hydraulic conductivity (Lp) refers to the ease with which water can flow from one location to another and therefore influences the rate of water movement [13]; Lp can be used to indicate the ability of plant roots to absorb water [15]. Under salinity stress, the maintenance of Lp is an essential part of the adaptation process that helps to restore plant growth [13].

During long-term exposure to salinity, plants undergo ionic stress, particularly due to sodium chloride, which causes plant nutritional imbalance and oxidative stress, with severe consequences for plant growth, development and survival $[4,10,12,16]$. Excess $\mathrm{Na}^{+}$is particularly deleterious to plants because it competes with $\mathrm{K}^{+}$for metabolic processes required for $\mathrm{K}^{+}$, leading to enzyme inactivation, plant nutritional imbalance, protein degradation, leaf photochemistry inhibition and oxidative stress [17]. All of these effects synergistically inhibit plant growth and development [10]. Previous studies have demonstrated that the $\mathrm{K}^{+} / \mathrm{Na}^{+}$ratio is considered an important indicator for evaluating the salinity resistance of various plant species $[4,18]$. The regulation of several genes encoding membrane transport proteins involved in $\mathrm{Na}^{+}$and/or $\mathrm{K}^{+}$uptake, translocation or compartmentalization is an important strategy for plants to address excessive $\mathrm{Na}^{+}$accumulation and $\mathrm{K}^{+}$ deficiency. The plasma membrane $\mathrm{Na}^{+} / \mathrm{H}^{+}$antiporter (SOS1, located in the plasma membrane) and the tonoplast
$\left(\mathrm{Na}^{+}, \mathrm{K}^{+}\right) / \mathrm{H}^{+}$antiporter $(\mathrm{NHX} 1$, located in the vacuolar membrane) can sequester $\mathrm{Na}+$ into vacuoles and play a major role in regulating cellular $\mathrm{pH}$ and $\mathrm{Na}^{+}$homeostasis $[9,19]$. The high-affinity potassium transporter 1 (HKT1) is involved in the control of $\mathrm{Na}^{+}$long distance transport by reabsorption of $\mathrm{Na}^{+}$from the xylem sap into the root cells, preventing the large accumulation of $\mathrm{Na}^{+}$in the aboveground tissue $[20,21]$. Moreover, the outward-rectifying $\mathrm{K}^{+}$ channel $(S K O R)$ mediates $\mathrm{K}^{+}$secretion from root cells into the xylem and $\mathrm{K}^{+}$transport to the shoots [22].

The use of biostimulants, which are kinds of natural or synthetic small bioactive molecules derived from humanor animal-related industrial processes, is considered an effective measure to ameliorate growth inhibition induced by salinity or to improve plant resistance to salinity stress $[10,23]$. The tertiary amine bioregulator 2-(3,4-dichlorophenoxy) triethylamine (DCPTA) represents a class of highly bioactive, low-molecular-weight amine compounds that have a significant regulatory effect on crop growth and development [24]. Previous studies have shown that DCPTA can improve the dry weight (DW) of tomato plants [25]; increase the root DW and leaf area of beet, radish [26], and maize [27]; and enhance ribulose-1,5bisphosphate activity and increase the size of chloroplasts in the leaves of sugar beet (Beta vulgaris L.) [28]. DCPTA can also enhance $\mathrm{CO}_{2}$ fixation in cotton, promote chlorophyll biosynthesis in guayule [29] and stimulate carotenoid biosynthesis in citrus [30]. Suitable concentrations of DCPTA can improve the net photosynthetic rate $\left(\mathrm{P}_{\mathrm{n}}\right)$ in maize (Zea mays L.) [31] and have anti-senescent properties, as demonstrated by the slowing of chlorophyll degradation in bean (Phaseolus vulgaris L.) leaf discs in darkness [32]. Moreover, DCPTA can increase the ability of crops to adapt to stress and improve stress resistance [33-36]. Xie et al. [35] showed that spraying DCPTA can increase the leaf relative water content (LRWC) and promote water uptake, as indicated by increased Lp, which may be due to improvements in root growth, increased photosynthetic capacity associated with the increased chlorophyll content, greater photosynthetic $\mathrm{C}_{4}$ enzyme activity and reduced damage to chloroplasts under drought stress, thereby increasing the drought tolerance of maize seedlings. DCPTA can also increase tolerance to low-temperature stress by increasing the maximum quantum efficiency of PSII photochemistry $\left(F_{\mathrm{v}} / F_{\mathrm{m}}\right)$ and the chlorophyll content, which effectively was shown to protect the photosynthetic system of maize leaves under low-temperature stress [33].

Maize is one of the most important cereal food crop species grown worldwide and provides raw materials for industry [37]. The area of maize production is the largest of food crop species, and its main planting areas are in irrigated agricultural areas in both arid and semi-arid regions. However, intensive irrigation results in high 
salinity levels [38]. The salinity-induced disturbance of nutritional status in growing cells inhibits maize growth and ultimately yield [39]. As maize is considered a moderately salinity-sensitive plant species [40], few salinitytolerant maize cultivars have been commercialized [41]. Therefore, soil salinity stress has become one of the most serious threats to sustainable maize production [40]. A previous study showed that addition of DCPTA can alleviate reductions in root DW caused by salinity stress [34]. However, little is known about how DCPTA applications and doses can trigger adaptation to $\mathrm{NaCl}$ stress via morpho-physiological responses and ion homeostasis, particularly the molecular mechanisms involved. Therefore, the aims of this study were the following: (1) to determine the effects of DCPTA on the leaf photosynthetic capacity and chlorophyll fluorescence of maize exposed to salinity stress, (2) to evaluate the responses of the leaf water status (leaf water potential $(\Psi \omega)$ and LRWC) and Lp of maize in response to applications of DCPTA under salinity stress, and (3) to explore the regulation of the concentration of $\mathrm{Na}^{+}$and $\mathrm{K}^{+}$and the $\mathrm{Na}^{+} / \mathrm{K}^{+}$ratio in the leaves and roots of maize and the expression of four genes (ZmSOS1, ZmHKT1, $Z m N H X 1$, and $Z m S K O R$ ) that encode transport proteins responsible for $\mathrm{Na}^{+}$and/or $\mathrm{K}^{+}$uptake, translocation or compartmentalization in response to DCPTA in the leaves and roots of maize subjected to salinity stress. This systematic investigation will provide additional information for an improved understanding of the regulatory mechanisms of DCPTA-mediated salinity stress tolerance in maize.

\section{Results}

Exogenous DCPTA alleviates salinity-induced plant growth and biomass accumulation reductions

The DWs of root and shoot, and root length, surface area and volume of maize were significantly affected by $\mathrm{NaCl}$ and DCPTA $(P \leq 0.001)$, and the interaction between $\mathrm{NaCl}$ and DCPTA application rate had significant effect on the root length (Table 1). As shown in Fig. 1 and Fig. 2, under non-stressed conditions, low doses of DCPTA $(20 \mu \mathrm{M}$ and $100 \mu \mathrm{M})$ significantly increased the DWs of root and shoot, and the root length, surface area and volume, while a relatively high concentration of DCPTA $(400 \mu \mathrm{M})$ had no significant effect on these indicators. Compared with non-salinity conditions, salinity stress significantly inhibited plant growth $(P \leq 0.05)$, and the DWs of root and shoot, and the root length, surface area and volume were reduced by 40.0, 30.1, 47.7, 46.4 and $37.5 \%$, respectively. However, $\mathrm{NaCl}$-induced reduction in the DWs of root and shoot and root volume were alleviated by applications of DCPTA at $20-400 \mu \mathrm{M}$, and the decreases in root length and root surface area were alleviated by applications of DCPTA at 20 and $100 \mu \mathrm{M}$, whereas $100 \mu \mathrm{M}$ DCPTA appeared to be the most effective concentration for alleviating salinity stress. Under salinity-stressed conditions, compared with those of untreated maize, the DWs of root and shoot, and the root length, surface area and volume of maize treated with $100 \mu \mathrm{M}$ DCPTA significantly improved by $33.4,26.2,39.4$, 37.2 and $29.2 \%$, respectively.

Table 1 Analysis of variance and mean comparisons for plant dry weight (Shoot DW: shoot dry weight; Root DW: root dry weight), leaf water status (RWC: relative water content; $\psi_{\text {w: }}$ leaf water potential), root hydraulic conductance $(L p)$ of maize plants grown under two salinity levels and treated with DCPTA at four rates of application

\begin{tabular}{|c|c|c|c|c|c|c|c|c|}
\hline $\begin{array}{l}\text { Source of } \\
\text { variation }\end{array}$ & $\begin{array}{l}\text { Shoot DW } \\
\text { (g.plant }^{-1} \text { ) }\end{array}$ & $\begin{array}{l}\text { Root DW } \\
\text { (g.plant }\end{array}$ & $\begin{array}{l}\text { Root length } \\
\left(\mathrm{cm} \cdot \text { plant }^{-1} \text { ) }\right.\end{array}$ & $\begin{array}{l}\text { Root surface area } \\
\left(\mathrm{cm}^{2} \cdot \text { plant }^{-1}\right)\end{array}$ & $\begin{array}{l}\text { Root volume } \\
\left(\mathrm{cm}^{3} \text {. plant }\right.\end{array}$ & $\psi_{\mathrm{W}}(\mathrm{MPa})$ & RWC (\%) & $\begin{array}{l}\mathrm{Lp} \\
\left(10^{-8} \cdot \mathrm{m}^{3} \cdot \mathrm{m}^{-2} \cdot \mathrm{s}^{-1} \mathrm{MPa}^{-1}\right)\end{array}$ \\
\hline \multicolumn{9}{|c|}{$\mathrm{NaCl}(\mathrm{mM})(\mathrm{N})$} \\
\hline 0 & $0.19 \pm 0.02 a$ & $0.12 \pm 0.01 a$ & $475.64 \pm 26.49 a$ & $120.12 \pm 9.24 a$ & $3.95 \pm 0.26 a$ & $-0.73 \pm 0.06 a$ & $93.34 \pm 2.43 a$ & $11.63 \pm 0.75 a$ \\
\hline 150 & $0.13 \pm 0.02 b$ & $0.09 \pm 0.01 b$ & $279.30 \pm 52.22 b$ & $71.97 \pm 10.93 b$ & $2.68 \pm 0.32 b$ & $-1.69 \pm 0.19 b$ & $71.99 \pm 6.25 b$ & $6.00 \pm 1.18 b$ \\
\hline \multicolumn{9}{|l|}{$\begin{array}{l}\text { DCPTA } \\
(\mu M)(D)\end{array}$} \\
\hline 0 & $0.14 \pm 0.04 b$ & $0.10 \pm 0.02 a$ & $346.20 \pm 116.42 a$ & $86.95 \pm 28.69 a$ & $3.10 \pm 0.78 a$ & $-1.28 \pm 0.62 \mathrm{a}$ & $78.38 \pm 15.69 a$ & $8.03 \pm 3.45 a$ \\
\hline 20 & $0.17 \pm 0.04 a b$ & $0.11 \pm 0.02 a$ & $384.99 \pm 118.35 a$ & $101.75 \pm 26.51 a$ & $3.24 \pm 0.75 a$ & $-1.24 \pm 0.58 a$ & $84.52 \pm 10.90 a$ & $8.60 \pm 3.22 \mathrm{a}$ \\
\hline 100 & $0.18 \pm 0.03 a$ & $0.11 \pm 0.02 a$ & $420.48 \pm 73.39 a$ & $103.32 \pm 22.29 a$ & $3.60 \pm 0.60 a$ & $-1.09 \pm 0.34 a$ & $85.38 \pm 8.60 \mathrm{a}$ & $9.89 \pm 2.42 \mathrm{a}$ \\
\hline 400 & $0.16 \pm 0.03 a b$ & $0.11 \pm 0.02 a$ & $358.22 \pm 116.24 a$ & $92.16 \pm 27.96 a$ & $3.32 \pm 0.69 a$ & $-1.23 \pm 0.50 a$ & $82.35 \pm 11.40 a$ & $8.74 \pm 3.01 a$ \\
\hline \multicolumn{9}{|l|}{ Significance } \\
\hline $\begin{array}{l}\mathrm{NaCl} \\
(\mathrm{mM})(\mathrm{N})\end{array}$ & $* * *$ & $* * *$ & $* * *$ & $* * *$ & $* * *$ & $* * *$ & $* * *$ & $* * *$ \\
\hline $\begin{array}{l}\text { DCPTA } \\
(\mu M)(D)\end{array}$ & $* * *$ & $* * *$ & $* * *$ & $* * *$ & $* * *$ & $* * *$ & $* * *$ & $* * *$ \\
\hline$N \times D$ & ns & ns & $* *$ & ns & ns & $* *$ & $* *$ & * \\
\hline
\end{tabular}

ns, ${ }^{*}, *$, and ${ }^{* * *}$ : Not significant or significant at $P \leq 0.05,0.01$, and 0.001 , respectively. The different letters within each column indicate significant differences according to Duncan's multiple-range test $(P=0.05)$ 


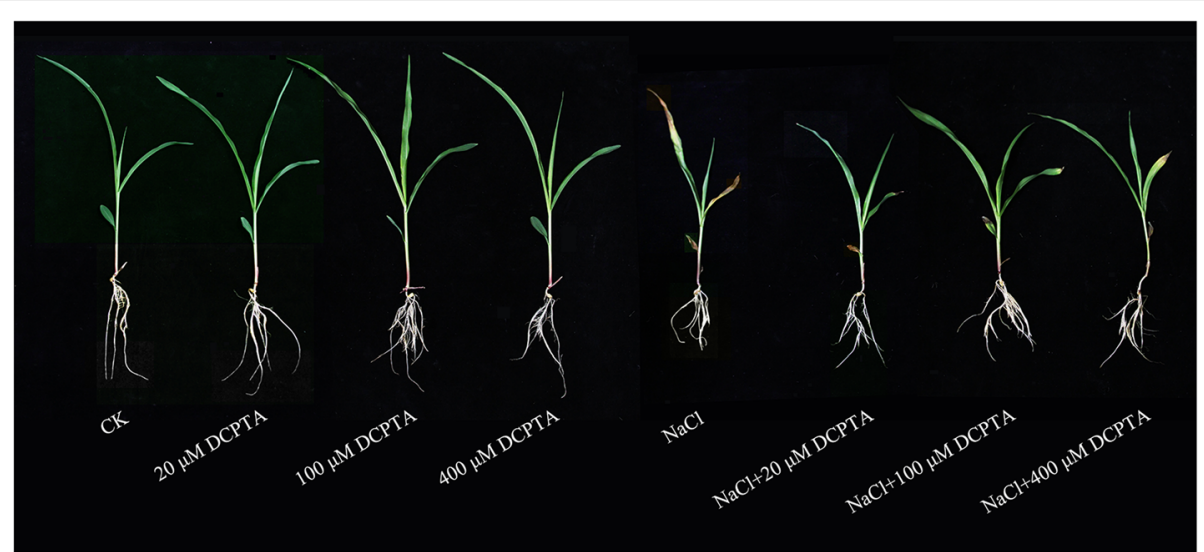

Fig. 1 Effects of DCPTA on the growth performance of non-stressed or salinity-stressed maize plants. The plants were grown in a hydroponic solution that contained $0,20,100$, or $400 \mu \mathrm{M}$ DCPTA with or without $150 \mathrm{mM} \mathrm{NaCl}$

Exogenous DCPTA maintains LRWC, leaf $\Psi \omega$ and root Lp The LRWC, leaf $\Psi \omega$ and root Lp were significantly affected by DCPTA and $\mathrm{NaCl}$ concentration; the interaction between DCPTA and $\mathrm{NaCl}$ concentration was significant (Table 1). Under the non-salinity conditions, application of DCPTA had no significant effect on leaf $\Psi \omega$ or LRWC; however, compared with the control, $100 \mu \mathrm{M}$ DCPTA stimulated significant increases in Lp, which increased by $14.7 \%$ (Fig. 3).
Compared with the non-stressed conditions, the salinity stress reduced the leaf $\Psi \omega$, LRWC and Lp by $76.43,45.56$ and $57.4 \%$, respectively. The $\mathrm{NaCl}-$ induced decreases in leaf $\Psi \omega$ and Lp were alleviated in plants treated with DCPTA at $20 \mu \mathrm{M}$ and $100 \mu \mathrm{M}$ - more markedly with the latter; however, the reduction in LRWC was alleviated in plants treated with DCPTA $(20-400 \mu \mathrm{M})$, especially with DCPTA at $100 \mu \mathrm{M}$. Compared with salinity stress alone, the

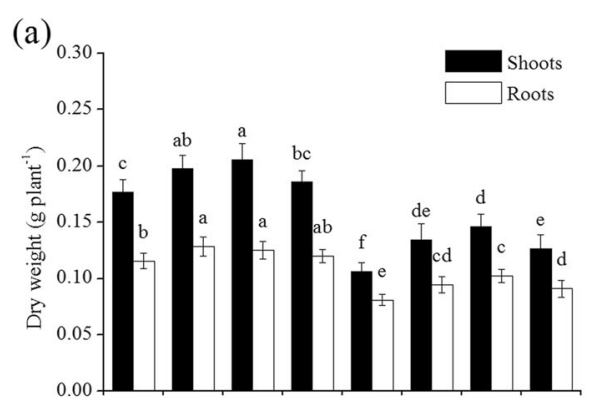

(c)

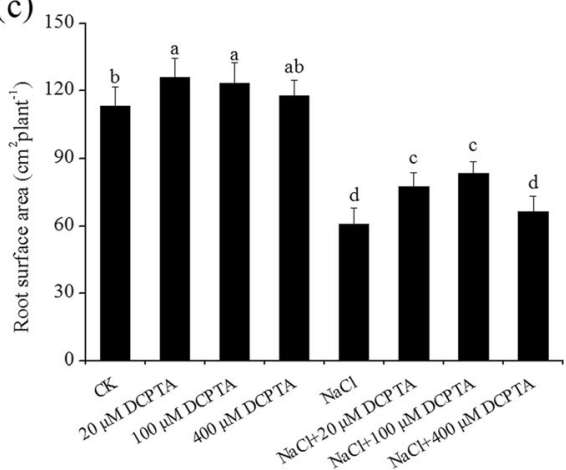

(b) 600

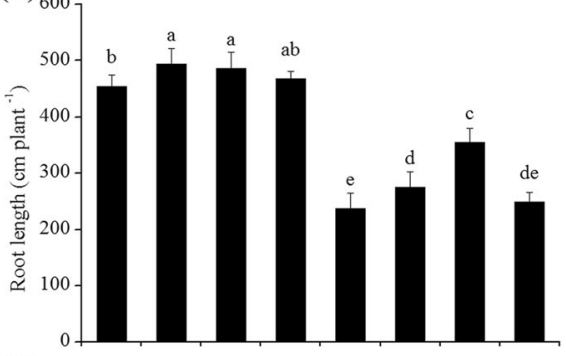

(d)

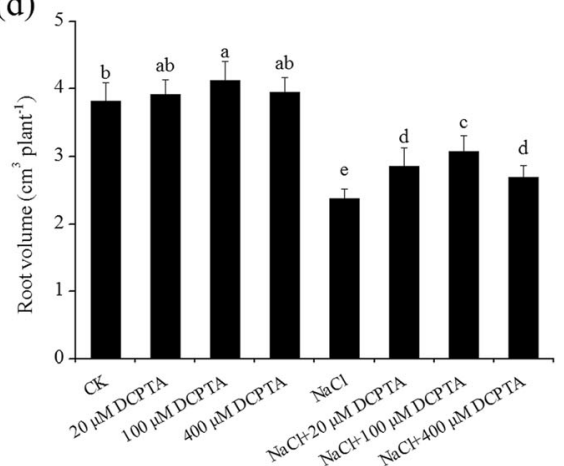

Fig. 2 Effects of DCPTA on the DWs of shoot and roots (a), root length (b), root surface area (c), and root volume (d) of non-stressed and salinitystressed maize plants. The plants were grown in a hydroponic solution that contained 0, 20, 100, or $400 \mu \mathrm{M} \mathrm{DCPTA}$ with or without $150 \mathrm{mM}$ NaCl. The data are the means \pm SEs $(n=5)$. The different letters on the bars indicate significant differences according to Duncan's test $(P=0.05)$ 

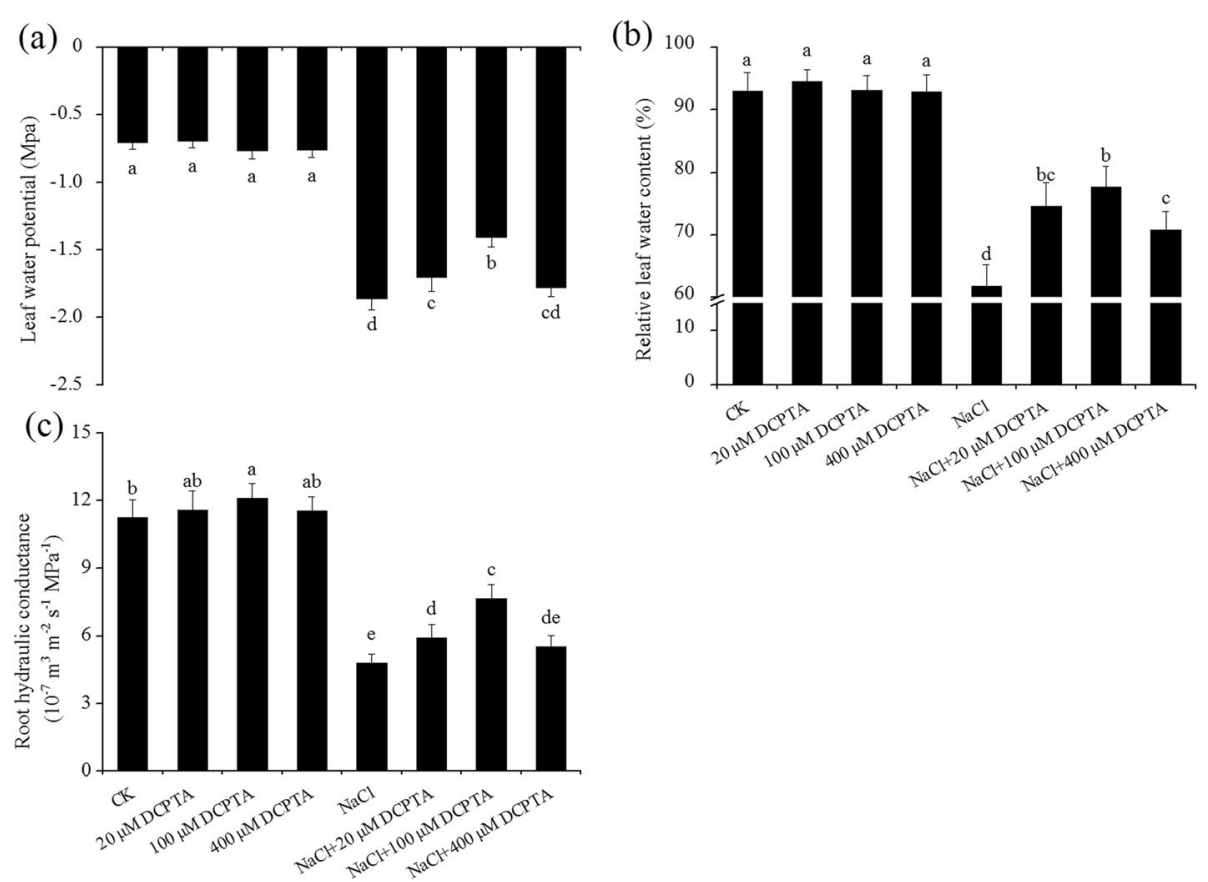

Fig. 3 Effects of DCPTA on the leaf $\psi \omega(\mathbf{a})$, LRWC (b), and root Lp (c) of non-stressed and salinity-stressed maize plants. The plants were grown in a hydroponic solution that contained $0,20,100$, or $400 \mu \mathrm{M}$ DCPTA with or without $150 \mathrm{mM} \mathrm{NaCl}$. The data are the means \pm SEs $(n=5)$. The different letters on the bars indicate significant differences according to Duncan's test $(P=0.05)$

application of $100 \mu \mathrm{M}$ DCPTA increased the leaf $\Psi \omega$, LRWC and Lp by $24.4,21.6$ and $59.8 \%$, respectively.

\section{Exogenous DCPTA improves photosynthetic pigment content and enhances photosynthetic capacity}

The contents of $\mathrm{Chl}$ a and $\mathrm{Chl} b$ were significantly affected by DCPTA and $\mathrm{NaCl}$ concentration, and the interaction between $\mathrm{NaCl}$ and DCPTA significantly affected the contents of $\mathrm{Chl} \mathrm{a}$ and Chl b (Table 2). Under the non-stressed conditions, applications of DCPTA at $20 \mu \mathrm{M}$ and $100 \mu \mathrm{M}$ stimulated significant increases in the contents of $\mathrm{Chl}$ a and $\mathrm{Chl} \mathrm{b}$, while $400 \mu \mathrm{M}$ DCPTA had no significant effect on chlorophyll content (Fig. 4). Compared with the non-stressed conditions, $\mathrm{NaCl}$ significantly affected $\mathrm{Chl}$ a and $\mathrm{Chl} b$ in maize and reduced their contents by 59.0 and $64.1 \%$, respectively. Under salinity stress conditions, the $20 \mu \mathrm{M}$ and $100 \mu \mathrm{M}$ DCPTA-treated plants presented a greater increase in the contents of both $\mathrm{Chl}$ a and $\mathrm{Chl} b$ than did the plants not treated with DCPTA, and the increase was greater with $100 \mu \mathrm{M}$ than with $20 \mu \mathrm{M}$ DCPTA. Compared with salinity stress alone, $100 \mu \mathrm{M}$ DCPTA increased the contents of $\mathrm{Chl}$ a and $\mathrm{Chl}$ b by 56.8 and $84.3 \%$, respectively.

The $\mathrm{P}_{\mathrm{n}}$, stomatal conductance $\left(\mathrm{g}_{\mathrm{s}}\right)$, intercellular $\mathrm{CO}_{2}$ concentration $\left(\mathrm{C}_{\mathrm{i}}\right)$ and transpiration rate $\left(\mathrm{T}_{\mathrm{r}}\right)$ were significantly affected by DCPTA and $\mathrm{NaCl}$ concentration. The interactive effects of DCPTA and $\mathrm{NaCl}$ concentration on the $P_{n}$ were significant (Table 2). Under non-stressed conditions, low doses of DCPTA $(20 \mu \mathrm{M}$ and $100 \mu \mathrm{M})$ significantly increased the $P_{n}$, while a relatively high concentration of DCPTA $(400 \mu \mathrm{M})$ had no significant effect on $P_{n}$ (Fig. 5a). The $P_{n}$ increased by 7.9 and $12.9 \%$ in plants treated with $20 \mu \mathrm{M}$ and $100 \mu \mathrm{M}$ DCPTA, respectively, compared with the plants treated without DCPTA under non-stressed conditions. $\mathrm{NaCl}$ markedly decreased the $P_{n}$ in maize leaves. Under stressed conditions, compared with that in non-DCPTA-treated plants, the $\mathrm{P}_{\mathrm{n}}$ in plants treated with DCPTA at concentrations of $20 \mu \mathrm{M}$ and $100 \mu \mathrm{M}$ increased by 19.1 and $40.7 \%$, respectively. Similarly, $g_{s}$ and $T_{r}$ were significantly reduced by salinity stress, and applications of DCPTA at $20 \mu \mathrm{M}$ and $100 \mu \mathrm{M}$ alleviated these adverse effects in the leaves of plants under stressed conditions (Fig. 5b and c). In contrast, salinity stress significantly stimulated an increase in $\mathrm{C}_{\mathrm{i}}$, but this induction was attenuated by pre-treatment with DCPTA at $100 \mu \mathrm{M}$ (Fig. 5d).

The $F_{\mathrm{v}} / F_{\mathrm{m}}$, PPSII, $\mathrm{qP}$ and NPQ were significantly affected by DCPTA and $\mathrm{NaCl}$ concentration. The interactions between DCPTA and $\mathrm{NaCl}$ concentration were significant (Table 2). Under non-stressed conditions, there was no effect of DCPTA on the obtained chlorophyll fluorescence parameters (Fig. 6). Compared with those in the control, the $F_{\mathrm{v}} / F_{\mathrm{m}}$, ФPSII and $\mathrm{qP}$ were markedly declined, and the NPQ was significantly 
Table 2 Analysis of variance and mean comparisons for chlorophyll content (Chl a: chlorophyll a; Chl b: chlorophyll b), photosynthetic parameters ( $P_{n}$ : net photosynthesis rate; $g_{s}$ : stomatal conductance; $C_{i}$ : intercellular $\mathrm{CO}_{2}$ concentration; $T_{r}$ : transpiration rate), chlorophyll fluorescence parameters ( $F_{v} / F_{m}$ : the maximum quantum efficiency of PSII photochemistry; DPSII: PSII operating efficiency; qP: photochemical quenching coefficient; NPQ: non-photochemical quenching) of maize plants grown under two salinity levels and treated with DCPTA at four rates of application

\begin{tabular}{|c|c|c|c|c|c|c|c|c|c|c|}
\hline $\begin{array}{l}\text { Source of } \\
\text { variation }\end{array}$ & $\begin{array}{l}\text { Chl a content } \\
\left(\mathrm{mg} \cdot \mathrm{g}^{-1} \mathrm{FW}\right)\end{array}$ & $\begin{array}{l}\text { Chl b content } \\
\left(\mathrm{mg} \cdot \mathrm{g}^{-1} \mathrm{FW}\right)\end{array}$ & $\begin{array}{l}P_{n} \\
\left(\mu \mathrm{mol} \cdot \mathrm{m}^{-2} \cdot \mathrm{s}^{-1}\right)\end{array}$ & $\begin{array}{l}g_{s} \\
\left(\mathrm{mmol} \cdot \mathrm{m}^{-2} \cdot \mathrm{s}^{-1}\right)\end{array}$ & $\begin{array}{l}T_{r} \\
\left(m m o l \cdot m^{-2} \cdot s^{-1}\right)\end{array}$ & $\begin{array}{l}C_{i} \\
\left(\mu \mathrm{mol} \cdot \mathrm{mol}^{-1}\right)\end{array}$ & $F_{\mathrm{v}} / F_{\mathrm{m}}$ & DPSII & $q^{P}$ & $\mathrm{NPQ}$ \\
\hline \multicolumn{11}{|l|}{$\begin{array}{l}\mathrm{NaCl} \\
(\mathrm{mM})(\mathrm{N})\end{array}$} \\
\hline 0 & $2.93 \pm 0.14 a$ & $0.80 \pm 0.06 a$ & $15.05 \pm 1.05 a$ & $0.08 \pm 0.01 a$ & $4.67 \pm 0.37 a$ & $224.69 \pm 21.53 b$ & $0.83 \pm 0.02 \mathrm{a}$ & $0.74 \pm 0.03 a$ & $0.64 \pm 0.04 a$ & $0.57 \pm 0.05 b$ \\
\hline 150 & $1.47 \pm 0.28 b$ & $0.37 \pm 0.09 b$ & $9.11 \pm 1.43 b$ & $0.05 \pm 0.01 b$ & $2.30 \pm 0.66 b$ & $337.81 \pm 46.68 \mathrm{a}$ & $0.58 \pm 0.07 b$ & $0.39 \pm 0.07 b$ & $0.40 \pm 0.06 b$ & $0.81 \pm 0.08 a$ \\
\hline \multicolumn{11}{|l|}{$\begin{array}{l}\text { DCPTA } \\
(\mu \mathrm{M})(\mathrm{D})\end{array}$} \\
\hline 0 & $2.00 \pm 0.89 a$ & $0.51 \pm 0.26 a$ & $11.00 \pm 3.50 a$ & $0.06 \pm 0.02 a$ & $3.13 \pm 1.61 a$ & $298.90 \pm 81.05 a$ & $0.67 \pm 0.17 a$ & $0.52 \pm 0.21 a$ & $0.48 \pm 0.17 a$ & $0.75 \pm 0.17 a$ \\
\hline 20 & $2.29 \pm 0.76 a$ & $0.60 \pm 0.24 a$ & $12.30 \pm 3.34 a$ & $0.07 \pm 0.02 \mathrm{a}$ & $3.62 \pm 1.34 a$ & $283.03 \pm 71.21 \mathrm{a}$ & $0.69 \pm 0.15 a$ & $0.56 \pm 0.22 \mathrm{a}$ & $0.54 \pm 0.13 a$ & $0.68 \pm 0.17 a$ \\
\hline 100 & $2.42 \pm 0.64 a$ & $0.67 \pm 0.19 a$ & $13.50 \pm 2.90 a$ & $0.07 \pm 0.01 \mathrm{a}$ & $3.87 \pm 0.73 a$ & $251.35 \pm 29.61 \mathrm{a}$ & $0.74 \pm 0.08 a$ & $0.60 \pm 0.14 a$ & $0.54 \pm 0.08 \mathrm{a}$ & $0.65 \pm 0.08 a$ \\
\hline 400 & $2.09 \pm 0.83 a$ & $0.56 \pm 0.24 a$ & $11.52 \pm 3.18 a$ & $0.06 \pm 0.02 a$ & $3.32 \pm 0.47 a$ & $291.72 \pm 76.25 a$ & $0.72 \pm 0.13 a$ & $0.58 \pm 0.19 a$ & $0.50 \pm 0.15 a$ & $0.68 \pm 0.13 a$ \\
\hline \multicolumn{11}{|l|}{ Significance } \\
\hline $\begin{array}{l}\mathrm{NaCl} \\
(\mathrm{mM})(\mathrm{N})\end{array}$ & $* * *$ & $* * *$ & $* * *$ & $* * *$ & $* * *$ & $* * *$ & $* * *$ & $* * *$ & $* * *$ & $* * *$ \\
\hline $\begin{array}{l}\text { DCPTA } \\
(\mu \mathrm{M})(\mathrm{D})\end{array}$ & $* * *$ & $* * *$ & $* * *$ & $* * *$ & *** & $* * *$ & $* * *$ & $* * *$ & $* * *$ & $* *$ \\
\hline$N \times D$ & $* *$ & $* *$ & $* *$ & ns & ns & ns & $* *$ & $* *$ & $* *$ & * \\
\hline
\end{tabular}

ns, ${ }^{*}, * *$, and ${ }^{* * *}$ : Not significant or significant at $P \leq 0.05,0.01$, and 0.001 , respectively. The different letters within each column indicate significant differences according to Duncan's multiple-range test $(P=0.05)$

increased in response to treatment with $150 \mathrm{mM} \mathrm{NaCl}$. The $\mathrm{NaCl}$-induced decreases in $F_{\mathrm{v}} / F_{\mathrm{m}}$ and ФPSII were alleviated by $100 \mu \mathrm{M}$ and $400 \mu \mathrm{M}$ DCPTA, especially with the former, while the decreases in $\mathrm{qP}$ were alleviated by applications of DCPTA at $20 \mu \mathrm{M}$ and $100 \mu \mathrm{M}-$ more markedly with the latter. $\mathrm{NaCl}$-induced increase in NPQ was attenuated by pre-treatment with DCPTA $(20-400 \mu \mathrm{M})$, and the effect of DCPTA was greater at $100 \mu \mathrm{M}$ than at $20 \mu \mathrm{M}$ and $400 \mu \mathrm{M}$. Compared with the salinity stress treatment, the DCPTA treatment at $100 \mu \mathrm{M}$ markedly increased the $F_{\mathrm{v}} / F_{\mathrm{m}}$ by $31.1 \%$, the
ФPSII by $49.5 \%$ and the qP by $45.2 \%$ and decreased the NPQ by $20.1 \%$.

\section{Exogenous DCPTA attenuates $\mathrm{Na}^{+}$toxicity, modulates $\mathrm{Na}^{+}$ and $\mathrm{K}^{+}$homeostasis}

$\mathrm{NaCl}$ and DCPTA significantly affected the contents of $\mathrm{Na}^{+}$and $\mathrm{K}^{+}$and the $\mathrm{Na}^{+} / \mathrm{K}^{+}$ratio in both the shoots and roots of maize plants $(P \leq 0.001)$. In addition, the interaction between $\mathrm{NaCl}$ and DCPTA significantly affected the contents of $\mathrm{Na}^{+}$and $\mathrm{K}^{+}$in both the shoots and roots, and the $\mathrm{Na}^{+} / \mathrm{K}^{+}$ratio in the roots of maize plants
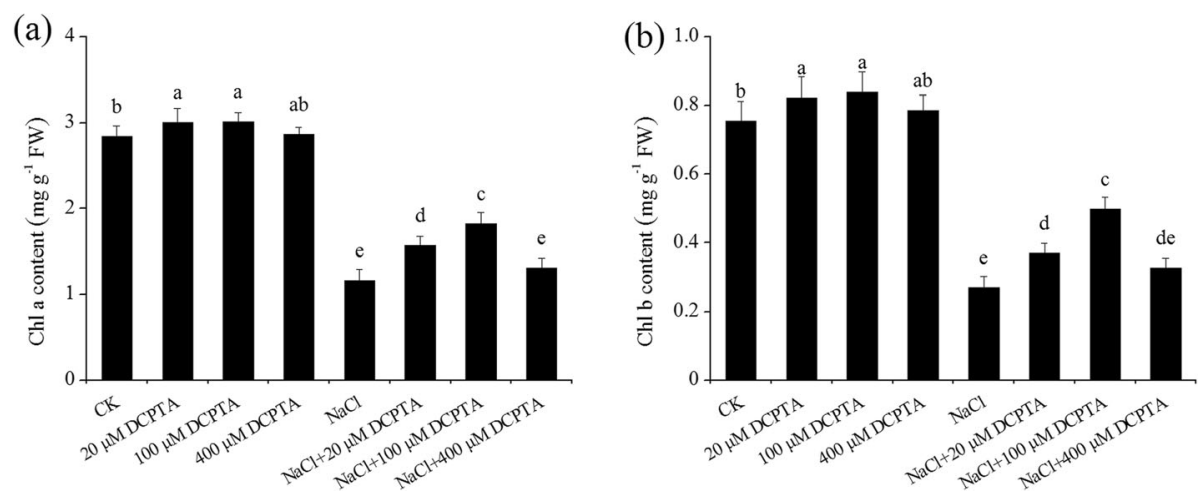

Fig. 4 Effects of DCPTA on the Chl a content (a) and Chl b content (b) in the leaves of non-stressed and salinity-stressed maize seedlings. The plants were grown in a hydroponic solution that contained 0, 20, 100, or $400 \mu \mathrm{M}$ DCPTA with or without $150 \mathrm{mM} \mathrm{NaCl}$. The data are the means \pm SEs $(n=5)$. The different letters on the bars indicate significant differences according to Duncan's test $(P=0.05)$ 

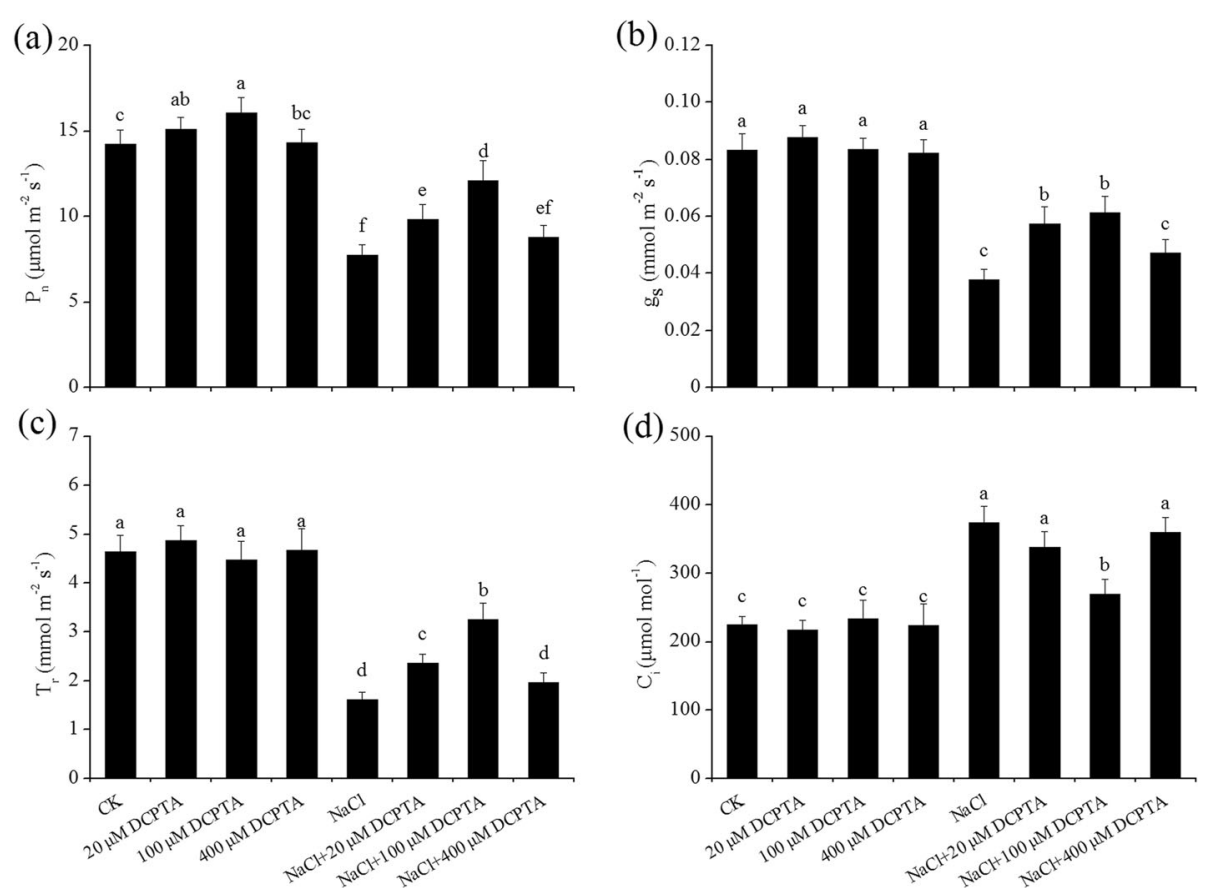

Fig. 5 Effects of DCPTA on the $P_{n}(\mathbf{a}), g_{s}(\mathbf{b}), T_{r}(\mathbf{c})$ and $C_{i}(\mathbf{d})$, of the leaves of non-stressed and salinity-stressed maize seedlings. The plants were grown in a hydroponic solution that contained $0,20,100$, or $400 \mu \mathrm{M}$ DCPTA with or without $150 \mathrm{mM} \mathrm{NaCl}$. The data are the means \pm SEs $(n=5)$. The different letters on the bars indicate significant differences according to Duncan's test $(P=0.05)$
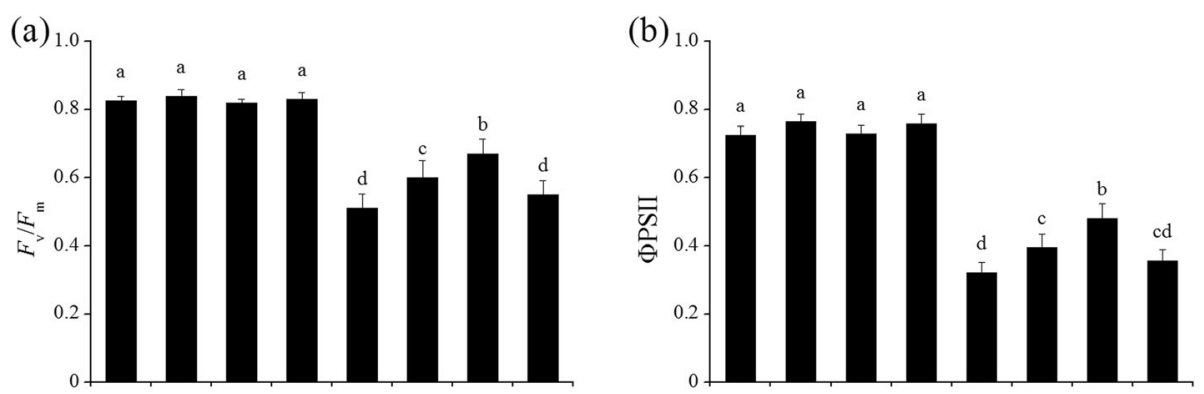

$(\mathrm{c})_{0.8}$

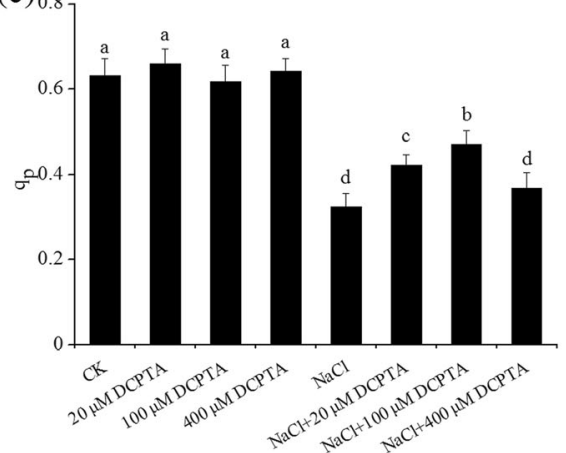

(d) 1

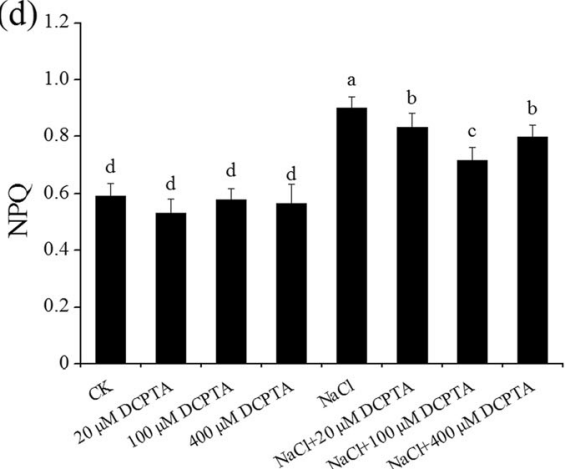

Fig. 6 Effects of DCPTA on the $F_{\mathrm{v}} / F_{\mathrm{m}}(\mathbf{a}), \mathrm{DPSII}(\mathbf{b}), \mathrm{qP}(\mathbf{c})$, and NPQ (d) of the leaves of non-stressed and salinity-stressed maize seedlings. The plants were grown in a hydroponic solution that contained $0,20,100$, or $400 \mu \mathrm{M}$ DCPTA with or without $150 \mathrm{mM} \mathrm{NaCl}$. The data are the means \pm SEs $(n=5)$. The different letters on the bars indicate significant differences according to Duncan's test $(P=0.05)$ 
(Table 3). As shown in Fig. 7, $150 \mathrm{mM} \mathrm{NaCl}$ significantly affected the concentrations of $\mathrm{Na}^{+}$and $\mathrm{K}^{+}$in both the roots and shoots of maize plants. In response to the 150 $\mathrm{mM} \mathrm{NaCl}$ treatment, the $\mathrm{Na}^{+}$concentrations in the roots and shoots increased by 5.5 and 9.8 times, respectively; the $\mathrm{K}^{+}$concentrations in the roots and shoots decreased by 69.2 and $49.3 \%$, respectively; and the $\mathrm{Na}^{+}$/ $\mathrm{K}^{+}$ratio in the roots and shoots increased by 20.4 and 21.4 times, respectively. Under non-stressed conditions, the application of DCPTA $(20-400 \mu \mathrm{m})$ have no effect on the $\mathrm{Na}^{+}$concentrations and $\mathrm{Na}^{+} / \mathrm{K}^{+}$ratio in both the roots and shoots, the $\mathrm{K}^{+}$concentrations in the shoots and the shoot/root $\mathrm{Na}^{+}$ratio of plants, while the application of $100 \mu \mathrm{m}$ DCPTA significantly increased the $\mathrm{K}^{+}$ concentrations in the roots. $\mathrm{NaCl}$ induced increases in $\mathrm{Na}+$ concentrations and decreases in $\mathrm{K}^{+}$concentrations, in both the shoots and roots, and these alterations were, in general, alleviated by the used of DCPTA. One hundred micromolar $(100 \mu \mathrm{M})$ of DCPTA appeared to be the most effective concentration for decreasing $\mathrm{Na}^{+}$ concentrations and increasing $\mathrm{K}^{+}$concentrations under salinity stress. DCPTA application significantly affected the $\mathrm{Na}^{+} / \mathrm{K}^{+}$ratio in both the roots and shoots of salinity-stressed plants. Under salinity stress, compared with those of non-DCPTA-treated plants, the $\mathrm{Na}^{+} / \mathrm{K}^{+}$ ratios of the shoots of plants treated with 20,100 and $400 \mu \mathrm{M}$ DCPTA decreased by 59.1, 68.6, and $39.7 \%$, respectively, and the ratio of $\mathrm{Na}^{+} / \mathrm{K}^{+}$in the roots decreased by $61.1,71.3$, and $22.3 \%$, respectively. Furthermore, the $\mathrm{NaCl}$-induced increases in the shoot/root $\mathrm{Na}^{+}$ratio were alleviated by applications of DCPTA $(20-400 \mu \mathrm{M})$, especially with DCPTA at $100 \mu \mathrm{M}$.
Exogenous DCPTA maintains $\mathrm{K}^{+} / \mathrm{Na}^{+}$homeostasis by altering the expression of ZmSOS1, ZmHKT1, ZmNHX1 and ZmSKOR

$\mathrm{NaCl}$ significantly affected the expression of ZmSOS1, $Z m N H X 1$ and ZmHKT1 in both the shoots and roots and $Z m S K O R$ in the roots of maize plants $(P \leq 0.001)$. DCPTA significantly affected the expression of ZmSOS1, $Z m N H X 1, Z m H K T 1$ and ZmSKOR in both the shoots and roots of maize plants. And the interaction between $\mathrm{NaCl}$ and DCPTA significantly affected the expression of ZmSOS1, ZmHKT1 in both the shoots and roots and $\mathrm{ZmNHX1}$ in the shoots of maize plants (Table 4). As shown in Fig. 8a, the expression of ZmSOS1 was significantly upregulated in both the roots and shoots of the plants treated with 20 and $100 \mu \mathrm{M}$ DCPTA under nonstressed conditions, and the plants treated with $100 \mu \mathrm{M}$ DCPTA under salinity-stressed conditions. As shown in Fig. 8 b, in the shoots, DCPTA application significantly increased ZmHKT1 expression under both stressed and non-stressed conditions. In the roots, DCPTA application significantly decreased ZmHKT1 expression under stressed conditions. Under both stressed and non-stressed conditions, the expression of $Z m N H X 1$ was significantly upregulated in the shoots (Fig. 8c) and the expression ZmSKOR was upregulated in both the roots and shoots of plants (Fig. 8d), in response to application of DCPTA at 20 and $100 \mu \mathrm{M}$ - more markedly with the latter.

\section{Discussion}

The harmful effects caused by salinity stress involve various physiological and biochemical mechanisms related to plant growth and development $[4,42]$. Biomass is a

Table 3 Analysis of variance and mean comparisons for ion concentrations $\left(\mathrm{K}^{+}\right.$and $\left.\mathrm{Na}^{+}\right)$in the shoots and roots of maize plants grown under two salinity levels and treated with DCPTA at four rates of application

\begin{tabular}{|c|c|c|c|c|c|c|}
\hline \multirow{2}{*}{$\begin{array}{l}\text { Source of } \\
\text { variation }\end{array}$} & \multicolumn{3}{|l|}{ Shoot } & \multicolumn{3}{|l|}{ Root } \\
\hline & $\begin{array}{l}\mathrm{Na}^{+} \text {content } \\
\left(\mathrm{mg} \cdot \mathrm{g}^{-1} \mathrm{DW}\right)\end{array}$ & $\begin{array}{l}\mathrm{K}^{+} \text {content } \\
\left(\mathrm{mg} \cdot \mathrm{g}^{-1} \mathrm{DW}\right)\end{array}$ & $\mathrm{Na}^{+} / \mathrm{K}^{+}$ratio & $\begin{array}{l}\mathrm{Na}^{+} \text {content } \\
\left(\mathrm{mg} \cdot \mathrm{g}^{-1} \mathrm{DW}\right)\end{array}$ & $\begin{array}{l}\mathrm{K}^{+} \text {content } \\
\left(\mathrm{mg} \cdot \mathrm{g}^{-1} \mathrm{DW}\right)\end{array}$ & $\mathrm{Na}^{+} / \mathrm{K}^{+}$ratio \\
\hline \multicolumn{7}{|l|}{$\mathrm{NaCl}(\mathrm{mM})(\mathrm{N})$} \\
\hline 0 & $2.43 \pm 0.29 b$ & $50.39 \pm 3.11 a$ & $21.11 \pm 0.01 a$ & $5.13 \pm 0.60 b$ & $22.57 \pm 2.03 a$ & $0.23 \pm 0.03 b$ \\
\hline 150 & $17.54 \pm 5.15 a$ & $33.05 \pm 6.67 b$ & $2.11 \pm 0.27 b$ & $29.20 \pm 5.36 a$ & $10.64 \pm 3.79 b$ & $3.27 \pm 1.64 a$ \\
\hline \multicolumn{7}{|l|}{ DCPTA $(\mu \mathrm{M})(\mathrm{D})$} \\
\hline 0 & $14.02 \pm 12.30 \mathrm{a}$ & $38.57 \pm 13.43 a$ & $11.37 \pm 0.50 a$ & $20.37 \pm 15.87 a$ & $14.27 \pm 8.04 a$ & $2.79 \pm 1.73 a$ \\
\hline 20 & $8.22 \pm 6.39 a$ & $43.34 \pm 8.83 a$ & $13.21 \pm 0.19 a$ & $16.34 \pm 11.34 a$ & $18.78 \pm 6.21 a$ & $1.15 \pm 0.98 a$ \\
\hline 100 & $7.65 \pm 5.51 \mathrm{a}$ & $46.11 \pm 5.80 a$ & $12.00 \pm 0.14 a$ & $13.64 \pm 9.73 a$ & $18.91 \pm 4.42 \mathrm{a}$ & $0.86 \pm 0.72 a$ \\
\hline 400 & $10.04 \pm 7.74 a$ & $38.86 \pm 10.58 a$ & $9.86 \pm 0.29 a$ & $18.30 \pm 14.24 a$ & $14.47 \pm 7.21 a$ & $2.19 \pm 1.08 a$ \\
\hline \multicolumn{7}{|l|}{ Significance } \\
\hline $\mathrm{NaCl}(\mathrm{mM})(\mathrm{N})$ & $* * *$ & $* * *$ & $* * *$ & $* * *$ & $* * *$ & $* * *$ \\
\hline DCPTA $(\mu \mathrm{M})(\mathrm{D})$ & $* * *$ & $* * *$ & $* *$ & $* * *$ & $* * *$ & $* * *$ \\
\hline $\mathrm{N} \times \mathrm{D}$ & $* * *$ & $* * *$ & ns & $* * *$ & $* * *$ & $* * *$ \\
\hline
\end{tabular}

ns, ${ }^{*}, * *$, and ${ }^{* * *}$ : Not significant or significant at $P \leq 0.05,0.01$, and 0.001 , respectively. The different letters within each column indicate significant differences according to Duncan's multiple-range test $(P=0.05)$ 

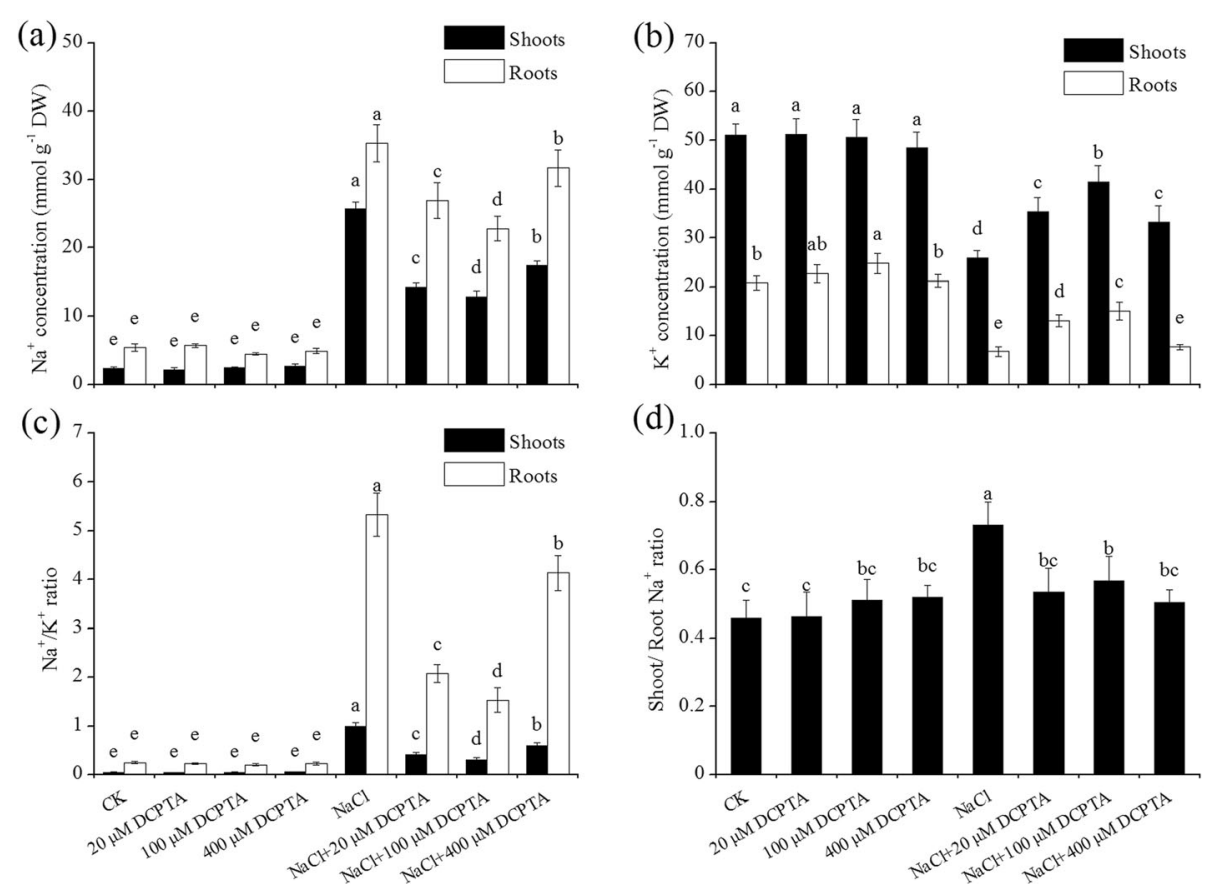

Fig. 7 Effects of DCPTA on the concentrations of $\mathrm{Na}^{+}$(a) and $\mathrm{K}^{+}$(b) and on the $\mathrm{Na}^{+} / \mathrm{K}^{+}$ratio $(\mathbf{c})$ in the leaves and roots and the shoot/root $\mathrm{Na}^{+}$ ratio (d) in non-stressed and salinity-stressed maize seedlings. The plants were grown in a hydroponic solution that contained 0, 20, 100, or $400 \mu \mathrm{M}$ DCPTA with or without $150 \mathrm{mM} \mathrm{NaCl}$. The data are the means \pm SEs $(n=5)$. The different letters on the bars indicate significant differences according to Duncan's test $(P=0.05)$

reliable indicator of plant responses to stress, and one of the primary effects of salinity stress is the inhibition of plant growth [4]. In this study, salinity stress significantly reduced the growth of maize seedlings, as indicated by the decreased DW of the roots and shoots of maize seedlings. However, the growth inhibition under salinity stress was alleviated by the application of DCPTA, particularly at $100 \mu \mathrm{M}$. Research has shown that there is a two-phase growth response to salinity: the growth is first reduced by the decrease in soil water potential and then by salt injury to the older leaves, because of a rapid rise in salt concentration in cell walls of cytoplasm when the

Table 4 Analysis of variance and mean comparisons for the expression of four genes (ZmSOS1, ZmHKT1, ZmNHX1, and ZmSKOR) responsible for $\mathrm{Na}^{+}$and/or $\mathrm{K}^{+}$uptake, transport and compartmentalization in the shoots and roots of maize plants grown under two salinity levels and treated with DCPTA at four rates of application

\begin{tabular}{|c|c|c|c|c|c|c|c|c|}
\hline \multirow{2}{*}{$\begin{array}{l}\text { Source of } \\
\text { variation }\end{array}$} & \multicolumn{4}{|c|}{ Relative expression (RQ) in shoots } & \multicolumn{4}{|c|}{ Relative expression (RQ) in roots } \\
\hline & ZmSOS1 & $Z m N H X 1$ & ZmHKT1 & ZmSKOR & ZmSOS1 & $Z m N H X 1$ & ZmHKT1 & ZmSKOR \\
\hline \multicolumn{9}{|l|}{$\mathrm{NaCl}(\mathrm{mM})(\mathrm{N})$} \\
\hline 0 & $1.94 \pm 0.80 \mathrm{~b}$ & $2.10 \pm 0.85 b$ & $1.62 \pm 0.50 b$ & $1.61 \pm 0.45 a$ & $1.70 \pm 0.50 b$ & $1.17 \pm 0.14 b$ & $0.95 \pm 0.13 b$ & $1.38 \pm 0.21 a$ \\
\hline 150 & $4.72 \pm 0.31 a$ & $6.20 \pm 1.85 a$ & $3.27 \pm 1.39 a$ & $1.51 \pm 0.53 a$ & $2.88 \pm 0.37 a$ & $2.35 \pm 0.19 a$ & $2.09 \pm 0.74 a$ & $0.98 \pm 0.25 b$ \\
\hline \multicolumn{9}{|l|}{ DCPTA $(\mu \mathrm{M})(\mathrm{D})$} \\
\hline 0 & $2.81 \pm 1.86 a$ & $2.47 \pm 1.58 b$ & $1.33 \pm 0.37 b$ & $0.95 \pm 0.14 b$ & $1.77 \pm 0.78 b$ & $1.69 \pm 0.68 \mathrm{a}$ & $2.06 \pm 1.05 \mathrm{a}$ & $0.90 \pm 0.25 b$ \\
\hline 20 & $3.78 \pm 1.01 \mathrm{a}$ & $4.67 \pm 2.03 a$ & $2.73 \pm 0.90 a$ & $1.82 \pm 0.26 a$ & $2.58 \pm 0.45 a$ & $1.77 \pm 0.58 \mathrm{a}$ & $1.37 \pm 0.53 b$ & $1.32 \pm 0.27 a$ \\
\hline 100 & $3.41 \pm 1.60 \mathrm{a}$ & $5.31 \pm 2.97 a$ & $3.28 \pm 1.58 \mathrm{a}$ & $1.91 \pm 0.19 a$ & $2.53 \pm 0.70 a$ & $1.82 \pm 0.66 a$ & $1.15 \pm 0.29 b$ & $1.33 \pm 0.17 a$ \\
\hline \multicolumn{9}{|l|}{ Significance } \\
\hline $\mathrm{NaCl}(\mathrm{mM})(\mathrm{N})$ & $* * *$ & $* * *$ & $* * *$ & ns & $* * *$ & $* * *$ & $* * *$ & $* * *$ \\
\hline DCPTA $(\mu \mathrm{M})(\mathrm{D})$ & $* * *$ & $* * *$ & $* * *$ & $* * *$ & $* * *$ & $* * *$ & $* * *$ & $* * *$ \\
\hline$N \times D$ & $* *$ & $* * *$ & $* * *$ & ns & * & ns & $* * *$ & ns \\
\hline
\end{tabular}

$\mathrm{ns},{ }^{*}, * *$, and ${ }^{* * *}$ : Not significant or significant at $P \leq 0.05,0.01$, and 0.001 , respectively. The different letters within each column indicate significant differences according to Duncan's multiple-range test $(P=0.05)$ 

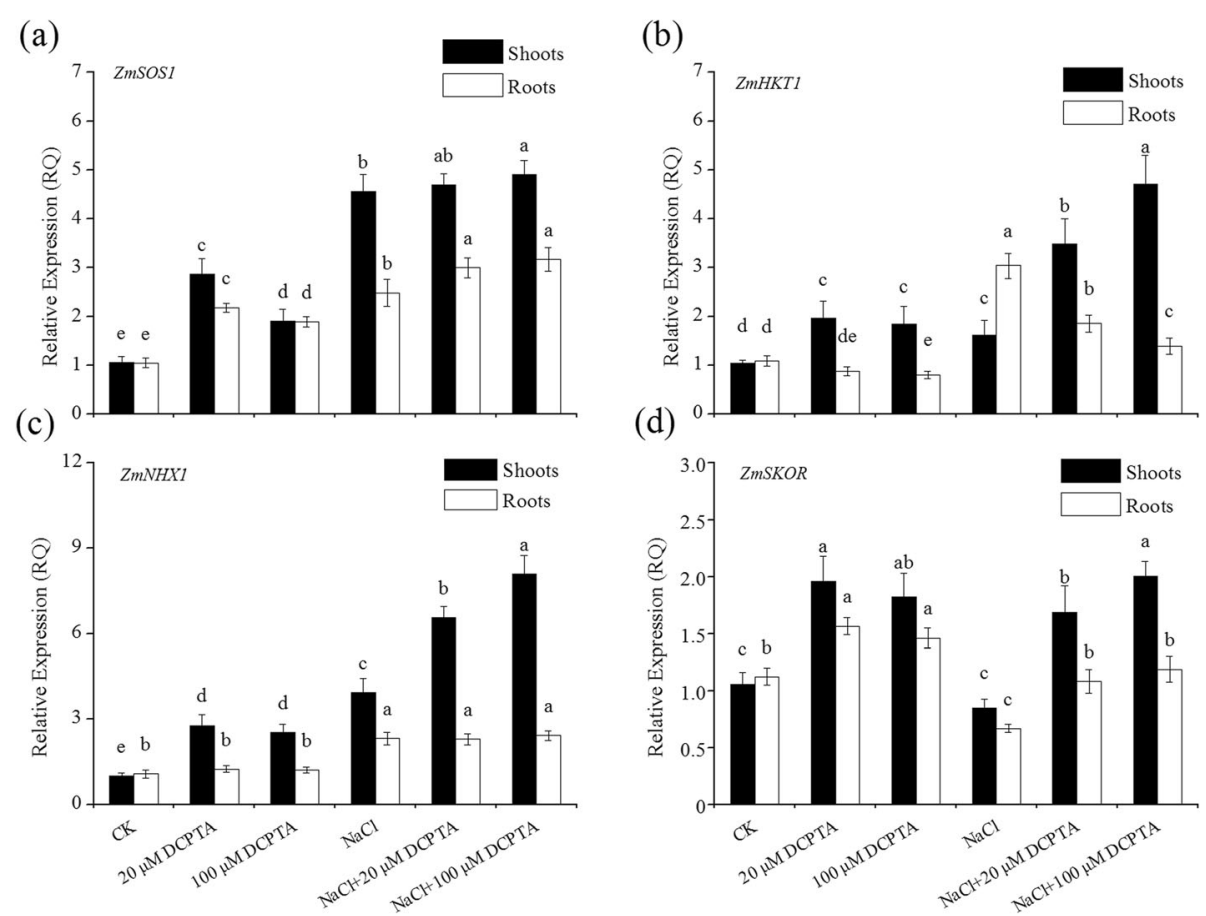

Fig. 8 Effects of DCPTA on the expression of ZmSOS1 (a), ZmHKT1 (b), ZmNHXI (c), and ZmSKOR (d) in the roots and leaves of non-stressed and salinity-stressed maize seedlings. The plants were grown in a hydroponic solution that contained $0,20,100$, or $400 \mu M$ DCPTA with or without $150 \mathrm{mM}$ $\mathrm{NaCl}$. The data are the means \pm SEs $(n=5)$. The different letters on the bars indicate significant differences according to Duncan's test $(P=0.05)$

vacuoles can no longer sequester incoming salts [4]. The promotion of DCPTA on the growth of maize seedlings under salinity stress may be related to the maintained water status and $\mathrm{K}^{+} / \mathrm{Na}^{+}$homeostasis. The beneficial influence of DCPTA on biomass production has also been reported for both soybean [43] and maize [35] under drought stress and for maize under lowtemperature stress $[33,36]$.

The reduction in plant growth under salinity conditions is due to the detrimental effect on bioenergetic processes of photosynthesis caused by salinity [1]. In this study, $\mathrm{NaCl}$ stress reduced the $\mathrm{P}_{\mathrm{n}}$ in maize seedlings. However, exogenous DCPTA (20 and $100 \mu \mathrm{M}$ ) alleviated $\mathrm{NaCl}$-induced inhibition in photosynthesis, which correlated with the improved biomass production in the shoots and roots of plants treated with DCPTA exposed to salinity conditions. Stomatal closure in response to decreases in leaf turgor to minimize water loss is an important response of plants to salinity stress, which is accompanied by notable declines in $\mathrm{g}_{\mathrm{s}}$, consequently, limited ambient $\mathrm{CO}_{2}$ diffusion to the site of carboxylation and stomatal limitation of photosynthesis [13]. Consistently, we also observed that $g_{s}$ significantly decreased in response to $\mathrm{NaCl}$ stress, and accompanied by a decrease in $T_{r}$. However, these reduction were alleviated by DCPTA (20 and $100 \mu \mathrm{M}$ ), which is consistent with the results of a previous study by Xie et al. [35] in which DCPTA exerted positive effects on plant photosynthetic capability. The increased $g_{s}$ and $T_{r}$ may be related to the maintained water status and the enhanced root water absorption capacity in DCPTA-treated plants, and thus reduce the stomatal limitation of photosynthesis [35]. In addition, salinity stress significantly increased the $\mathrm{C}_{\mathrm{i}}$, which may be due to decreased $\mathrm{CO}_{2}$ assimilation induced by photosystem photo-oxidation or damage and the inactivation of the photosynthesis enzymes under salinity stress [13]. Such results indicate that non-stomatal limitations were the primary cause of the decrease in the $P_{n}$ of plants grown under salinity conditions [44]. However, the increase in $C_{i}$ induced by salinity stress were alleviated by $100 \mu \mathrm{M}$ DCPTA, and the decreased $\mathrm{C}_{\mathrm{i}}$ in DCPTA-treated plants may be related to the enhanced $\mathrm{CO}_{2}$ assimilation capacity, which depends on the integrity of photosynthetic organ structure and function, and thus reduce the non-stomatal limitation of photosynthesis in DCPTA-treated plants [4]. The alleviation of stomatal and non-stomatal limitation by DCPTA contributed to improvements in photosynthetic capacity under salinity stress.

Chlorophylls are essential pigments that capture light energy and perform photosynthesis in plants. $F_{\mathrm{v}} / F_{\mathrm{m}}$, ФPSII and $\mathrm{qP}$ are parameters that reflect photochemical quenching, whereas NPQ reflects non-photochemical quenching [45]. In the current study, $\mathrm{NaCl}$ stress 
decreased the values of the chlorophyll contents, $F_{\mathrm{v}} / F_{\mathrm{m}}$, ФPSII and qP, and these reductions were alleviated with the application of DCPTA at $20 \mu \mathrm{M}$ and $100 \mu \mathrm{M}$. This suggests that exogenous DCPTA may enhance the ability to absorb and transform light energy and improve the quantum efficiency of PSII photochemistry, which would lead to enhanced photosynthesis under salinity conditions. In addition, exogenous DCPTA alleviated the salinity-induced decrease in $\mathrm{qP}$ and increase in NPQ, which indicated that DCPTA could promote the use efficiency of absorbed light in photochemical processes, with minimal thermal dissipation and fluorescence emissions [33, 35]. This is supported by the observation that DCPTA improved $P_{n}$ in maize seedlings under salinity stress. The increase of chlorophyll content and the improvement in PSII efficiency may be related to a promising role of DCPTA in protecting photosynthetic apparatus from oxidative damage under stress conditions $[35,46]$. Thus, these results indicated that, DCPTA improved PSII efficiency, which ultimately increased the photosynthetic capability and salinity tolerance of maize.

The promotion of increased plant biomass and photosynthetic capacity due to the effects of DCPTA can also be attributed to an amelioration of water status. In this study, the application of $20 \mu \mathrm{M}$ and $100 \mu \mathrm{M}$ DCPTA alleviated the decrease in water status under salinity stress, as indicated by the LRWC and leaf $\Psi \omega$, which may be attributed to the dynamic balance maintained between plant root water absorption and leaf transpiration [13]. Moreover, the relatively low reduction in the LRWC and leaf $\Psi \omega$ in the stressed plants treated with DCPTA was consistent with the relatively low reduction in $g_{s}$ and $T_{r}$ in those plants. Given that the beneficial effect of DCPTA on plant water status is due to an increase in root water absorption, which is largely achieved by improved root growth (which is associated with the root DW, length, surface area and volume) and Lp, not a decrease in water loss due to the increase in $g_{s}$ and $T_{r}$. These results suggest that DCPTA increased the root water uptake ability and thus improved the water status of maize plants under salinity stress.

Salts absorbed by the roots are transported to the shoots over long distances in the transpiration stream, and leaves are the main location of $\mathrm{Na}^{+}$accumulation in most plants [4]. In this study, the addition of DCPTA induced substantial decreases in the $\mathrm{Na}^{+}$concentration in the shoots, which was accompanied by a decreased shoot/root $\mathrm{Na}^{+}$ratio under salinity stress. To reduce cytoplasmic $\mathrm{Na}^{+}$concentrations, plants have evolved various adaptive mechanisms, including restricting $\mathrm{Na}^{+}$ uptake from the soil solution, extruding excessive $\mathrm{Na}^{+}$ and vacuolar partitioning of $\mathrm{Na}^{+}$to decrease $\mathrm{Na}^{+}$accumulation in the cytosol [47]. In this study, under salinity stress conditions, the expression of ZmSOS1 in the roots and shoots was upregulated, and DCPTA further upregulated the expression of ZmSOS1 in the roots; in turn, this upregulation decreased the $\mathrm{Na}^{+}$influx from the external solution into the cytosol or promoted $\mathrm{Na}^{+}$export to the apoplastic space $[11,48]$. Therefore, DCPTA may increase the capability of plants to extrude $\mathrm{Na}^{+}$into soil solution and/or mitigate the toxic effects of $\mathrm{Na}^{+}$, as the toxicity of $\mathrm{Na}^{+}$is small in the apoplastic space [49]. DCPTA increased shoot ZmHKT1 expression under salinity stress, which facilitated $\mathrm{Na}^{+}$recirculation into the xylem and $\mathrm{Na}^{+}$allocation to the roots. In contrast, DCPTA decreased ZmHKT1 expression in the roots, which reduced $\mathrm{Na}^{+}$loading into the xylem and subsequently transported $\mathrm{Na}^{+}$to sensitive photosynthetic tissues, suggesting that, compared with untreated plants, plants treated with DCPTA may be more capable of restricting $\mathrm{Na}^{+}$accumulation in sensitive tissues. $H K T$ transporters have been shown to mediate the translocation of $\mathrm{Na}^{+}$from the roots to the shoots by retrieving $\mathrm{Na}^{+}$from the root-to-shoot xylem sap, which represents a strategy to avoid the toxic effects of the photosynthetic apparatus [9, 42]. In this study, the dysregulation of ZmHKT1 under salinity stress and in response to DCPTA was correlated with the lower shoot/root $\mathrm{Na}^{+}$ ratio in the plants treated with DCPTA compared with the untreated plants. Increasing the expression of $Z m S O S 1$ in the roots and ZmHKT1 in the shoots while decreasing the expression of ZmHKT1 in the roots contributed to decreased $\mathrm{Na}^{+}$concentration in the shoots of the plants treated with DCPTA and could therefore be a key consequence of the effect of DCPTA on plants exposed to salinity stress. In addition, a recent study showed that $\mathrm{Na}$-acclimated maize plants have improved vacuolar $\mathrm{Na}^{+}$sequestration ability in their leaves and can accumulate relatively large amounts of $\mathrm{Na}^{+}$in those organs without any detrimental effects on photosynthetic capacity [50]. It has been proposed that $N H X$ functions in $\mathrm{Na}^{+}$compartmentalization in the vacuole and efflux of $\mathrm{Na}^{+}$from cells [4], and the upregulation of $N H X$ in transgenic plant species such as Brassica napus [51], poplar [52] and tomato [53] has been shown to increase plant salinity tolerance. Moreover, a previous study showed that salinity-tolerant maize hybrids exhibited higher expression of $Z m N H X 1$ than did salinity-sensitive hybrids exposed to salinity stress [54]. In this study, ZmNHX1 expression was upregulated in both roots and shoots of plants under salinity stress, and further upregulated in the shoots of DCPTA-treated plants under salinity conditions. The upregulation of $Z m N H X 1$ expression in the shoots in response to DCPTA was responsible for increased $\mathrm{Na}^{+}$ compartmentalization in the leaf vacuoles, which was beneficial for reducing the $\mathrm{Na}^{+}$toxicity in the cytosol, improving the osmolarity in the vacuole, and concomitantly enhancing plant salinity tolerance [55]. 
Owing to the similar hydration radius of $\mathrm{K}^{+}$and $\mathrm{Na}^{+}$, excess $\mathrm{Na}^{+}$osmoticum obviously competes for $\mathrm{K}^{+}$entry into the symplast at transport sites, which causes a reduction in $\mathrm{K}^{+}$concentration and alters the $\mathrm{Na}^{+} / \mathrm{K}^{+}$ratio under salinity stress [18]. In this study, DCPTA significantly increased the $\mathrm{K}^{+}$concentration and decreased the $\mathrm{Na}^{+} / \mathrm{K}^{+}$ratio in the plants under salinity stress, which was presumably crucial for salinity tolerance [4]. It has been shown that the SKOR channel influences the xylem loading of $\mathrm{K}^{+}[16]$. In this study, DCPTA significantly upregulated the expression of ZmSKOR in plants exposed to $150 \mathrm{mM} \mathrm{NaCl}$, which may have contributed to $\mathrm{K}^{+}$release into the xylem for transport towards the shoots $[22,56]$ and was correlated with increased $\mathrm{K}^{+}$ concentration in plants treated with DCPTA in this study. Moreover, the upregulation of $Z m S K O R$ in combination with ZmSOS1 and ZmHKT1 in the shoots as well as the downregulation of $Z m H K T 1$ in the roots of plants treated with DCPTA can account for the reduced $\mathrm{Na}^{+} / \mathrm{K}^{+}$ratio of plants under salinity stress.

\section{Conclusions}

In conclusion, we have demonstrated that $100 \mu \mathrm{M}$ DCPTA can enhance the salinity stress tolerance of maize seedlings. DCPTA improved the photosynthetic capacity of maize plants by regulating stomatal movement and improving both light energy absorption and electron transport in PSII; DCPTA maintained the water status by promoting root growth and improving root water uptake ability, which contributed to water transport to specific tissues and $\mathrm{CO}_{2}$ diffusion across the plasma membrane; In addition, DCPTA pre-treatment decreased the $\mathrm{Na}^{+}$concentration and increased the $\mathrm{K}^{+}$ concentration by altering the expression of four genes (ZmSOS1, ZmHKT1, ZmNHX1 and ZmSKOR) that encode membrane transport proteins responsible for $\mathrm{K}^{+} /$ $\mathrm{Na}^{+}$homeostasis under salinity stress. The improved photosynthesis, water status, and $\mathrm{K}^{+} / \mathrm{Na}^{+}$homeostasis contributed to improved growth and salinity stress tolerance (Fig. 9). Thus, applications of appropriate concentration DCPTA can be a sustainable approach to increase crop yields under salinity stress.

\section{Methods}

Plant growth conditions, stress treatments and sampling Seeds of maize (cultivar ZD958, a local commonly planted cultivar) (Beijing De Nong Seed Industry Co., Ltd., Beijing, China) were surface sterilized for $10 \mathrm{~min}$

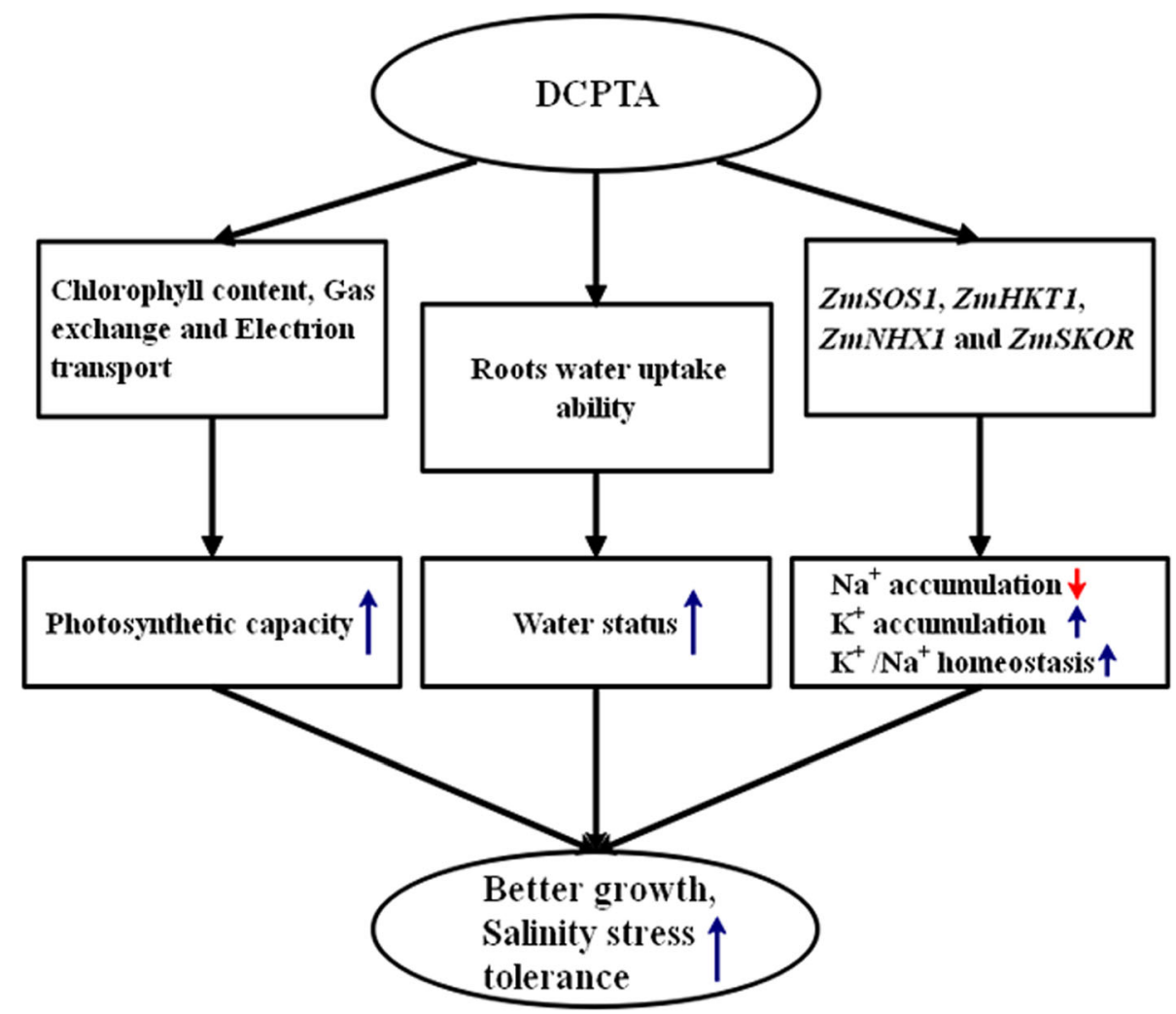

Fig. 9 Schematic representation of the positive role of DCPTA on the salinity tolerance of maize. A model was developed to show that the photosynthetic capacity, water status, accumulation of $\mathrm{Na}^{+}$and $\mathrm{K}^{+}$and the $\mathrm{Na}^{+} / \mathrm{K}^{+}$ratio were regulated by DCPTA in maize under salinity stress. The blue arrows $(\uparrow)$ and the red arrows $(\downarrow)$ represent the positive and passive roles of DCPTA, respectively 
with mercuric chloride $(0.2 \%)$ and then rinsed abundantly with distilled water. Afterward, the seeds were soaked in distilled water for $12 \mathrm{~h}$ and then germinated on double-layered filter paper moistened with distilled water at $28{ }^{\circ} \mathrm{C}$ for 2 days in the dark. The germinated seeds were sown in quartz sand in a climate chamber (HPG-280HX, Harbin Donglian Electronic Technology Development Co., Ltd., Harbin, China) whose temperature was set to $28^{\circ} \mathrm{C} / 18^{\circ} \mathrm{C}$, corresponding to a $12 \mathrm{~h} / 12 \mathrm{~h}$ (day/night) photoperiod; the light intensity in the chamber was $350-450 \mu \mathrm{mol} \cdot \mathrm{m}^{-2} \cdot \mathrm{s}^{-1}$, and the relative humidity was $50-60 \%$. Two-leaf-stage seedlings of uniform size were transferred to plastic pots $(40.5 \mathrm{~cm} \times$ $32.5 \mathrm{~cm} \times 12 \mathrm{~cm}, 12$ plants per pot) containing $1 / 2$ strength Hoagland nutrient solution ( $\mathrm{pH}$ 6.5). The nutrient solution was changed every 3 days to avoid nutrient depletion. The nutrient solution comprised the following components: $2.5 \mathrm{mM} \mathrm{Ca}\left(\mathrm{NO}_{3}\right)_{2}, 1.0 \mathrm{mM} \mathrm{K} \mathrm{K}_{2}, 0.2$ $\mathrm{mM} \mathrm{KH} \mathrm{PO}_{4}, 0.6 \mathrm{mM} \mathrm{MgSO}, 2.5 \mathrm{mM} \mathrm{CaCl} 2,0.5 \mathrm{mM}$ $\mathrm{NaCl}, 1.0 \mu \mathrm{M} \mathrm{H}_{3} \mathrm{BO}_{4}, 2.0 \mu \mathrm{M} \mathrm{MnSO}_{4}, 0.5 \mu \mathrm{M} \mathrm{ZnSO}$, $0.3 \mu \mathrm{M} \mathrm{CuSO}{ }_{4}, 0.005 \mu \mathrm{M}\left(\mathrm{NH}_{4}\right)_{6} \mathrm{Mo}_{7} \mathrm{O}_{24}$, and $200 \mu \mathrm{M}$ Fe-EDTA. When the seedlings grew to the three-leaf stage, they were treated with the following different nutrient solutions: (1) 1/2-strength Hoagland nutrient solution (CK); (2) 1/2-strength Hoagland nutrient solution + $20 \mu \mathrm{M}$ DCPTA (20 $\mu \mathrm{M}$ DCPTA); (3) $1 / 2$-strength Hoagland nutrient solution $+100 \mu \mathrm{M}$ DCPTA $(100 \mu \mathrm{M}$ DCPTA); (4) 1/2-strength Hoagland nutrient solution + $400 \mu \mathrm{M}$ DCPTA (400 $\mu \mathrm{M}$ DCPTA); (5) $150 \mathrm{mM} \mathrm{NaCl}$ in 1/2-strength Hoagland nutrient solution $+0 \mu \mathrm{M}$ DCPTA $(\mathrm{NaCl}) ;(6) 150 \mathrm{mM} \mathrm{NaCl}$ in $1 / 2$-strength Hoagland nutrient solution $+20 \mu \mathrm{M}$ DCPTA $(\mathrm{NaCl}+20 \mu \mathrm{M}$ DCPT A); (7) $150 \mathrm{mM} \mathrm{NaCl}$ in 1/2-strength Hoagland nutrient solution $+100 \mu \mathrm{M}$ DCPTA $(\mathrm{NaCl}+100 \mu \mathrm{M}$ DCPTA $)$; and (8) $150 \mathrm{mM} \mathrm{NaCl}$ in $1 / 2$-strength Hoagland nutrient solution $+400 \mu \mathrm{M}$ DCPTA $(\mathrm{NaCl}+400 \mu \mathrm{M}$ DCPTA $)$. The DCPTA (Zhengzhou Zhengshi Chemical Limited Co., Ltd., China) was applied 2 days before the addition of $\mathrm{NaCl}$ in the nutrient solution. The $\mathrm{NaCl}$ concentration was gradually increased in $50 \mathrm{mM}$ increments every $8 \mathrm{~h}$ to avoid salinity shock. The experiment included 8 treatments with 5 replicates $(90$ plants in total per treatment). Each replicate included 18 plants (selected from 2 pots of 12 plants each). Five days after the salinity level reached $150 \mathrm{mM}$, the gas exchange, chlorophyll fluorescence parameters, LRWC and leaf $\Psi \omega$ were measured for the second fully expanded leaf, and the root Lp was measured. The plants in the 8 treatments were then collected, frozen immediately in liquid nitrogen and stored at $-80^{\circ} \mathrm{C}$ until the plant biomass determination and biochemical assays.

In the second experiment, the plants were cultivated in the same manner as described above. After $24 \mathrm{~h}$ of salinity treatment $(0$ and $150 \mathrm{mM} \mathrm{NaCl})$ in combination with DCPTA $(0,20$ and $100 \mu \mathrm{M})$, the leaves and roots of the maize seedlings of 6 treatments (including five replicates) were sampled by mixing 5 seedlings per replicate, frozen immediately in liquid nitrogen and then stored at $-80^{\circ} \mathrm{C}$ for RT-qPCR .

\section{Analysis of plant growth, root characteristic parameters and ion concentrations}

After 5 days of the treatments, the plants were divided into two parts: roots and shoots. The root characteristic parameters, including the root length, surface area, and volume, were then scanned with a root scanner (MRS9600TFU2L, Shanghai Microtek Technology Co., Ltd. Shanghai, China). The roots and shoots were subsequently dried in an oven at $80^{\circ} \mathrm{C}$ to a constant weight to determine the DW. The dry samples of the roots and shoots were ground into a fine powder and passed through a $1 \mathrm{~mm}$ diameter mesh stainless steel sieve. Afterward, $0.1 \mathrm{~g}$ of the root and shoot samples was digested with a $5 \mathrm{~mL}$ of a $\mathrm{HNO}_{3}: \mathrm{HClO}_{4}(5: 1 \mathrm{v} / \mathrm{v})$ solution at $80^{\circ} \mathrm{C}$ until the sample consisted of only a small white residue. The sample was then brought to $50 \mathrm{~mL}$ with deionized water. The contents of $\mathrm{K}^{+}$and $\mathrm{Na}^{+}$in the roots and shoots were analysed by flame atomic absorption spectrophotometry (Z-2000; Hitachi, Japan).

\section{Determination of LRWC}

To analyse the LRWC, the second fully expanded leaves were collected and weighed to determine the fresh weight (FW), after which they were immersed in distilled water for $24 \mathrm{~h}$ in the dark. The leaves were subsequently gently blotted dry with absorbent paper and weighed to determine their turgid weight (TW). The samples were then dried in an oven at $105^{\circ} \mathrm{C}$ for 20 min followed by $80^{\circ} \mathrm{C}$ until a constant weight was achieved, at which point the DW was determined. The LRWC was calculated using the following formula: LRWC $(\%)=[(\mathrm{FW}$ DW) / (TW - DW) ] $\times 100$.

\section{Measurement of leaf $\Psi_{\omega}$}

The leaf $\Psi \omega$ of the second fully expanded leaves was determined by the pressure chamber technique (type 3115 pressure chamber, Beijing Huahai Heng Hui Technology Co., Ltd. Beijing, China). The second fully expanded leaves were harvested and inserted immediately into the rubber plug hole of the pressure chamber such that the incision was exposed approximately a few millimetres outside the sealing ring for convenient observation. After a good seal was confirmed, the pressure control valve was rotated to slowly pressurize at $0.05 \mathrm{MPa} \cdot \mathrm{s}^{-1}$. When a water film appeared at the incision, rotating of the control valve was stopped, and the pressure value at this time was recorded as the leaf $\Psi \omega$. 


\section{Measurement of chlorophyll content}

To measure the chlorophyll content in the leaves, a fresh leaf sample $(0.5 \mathrm{~g})$ and $5 \mathrm{~mL}$ of acetone $(80 \% \mathrm{v} / \mathrm{v})$ were homogenized together in an ice bath. After centrifugation at $10,000 \mathrm{~g}$ for $10 \mathrm{~min}$ at $4{ }^{\circ} \mathrm{C}$, the absorbance at 645 and $663 \mathrm{~nm}$ was monitored spectrophotometrically with a spectrophotometer (UV-5500, Shanghai Yuan Analysis Instrument Co., Ltd., China) to determine the contents of chlorophyll a ( $\mathrm{Chl}$ a) and chlorophyll b $(\mathrm{Chl} \mathrm{b})$, respectively. These contents were calculated in accordance with the equations of Arnon [57].

\section{Determination of gas exchange parameters}

The gas exchange of attached leaves were determined with an LI-6400 portable photosynthetic system (LI-COR Inc., USA) at 9:00-11:00 a.m. for the different treatments of maize seedlings. The second fully expanded leaves were used for the assays. During the measurements, the leaf chamber temperature was maintained at approximately $26^{\circ} \mathrm{C}$, the photosynthetic photon flux density (PPFD) was $800 \mu \mathrm{mol} \mathrm{m}^{-2} \mathrm{~s}^{-1}$, the $\mathrm{CO}_{2}$ concentration was $400 \mu \mathrm{mol} \cdot \mathrm{mol}^{-1}$, and the relative humidity was $60-70 \%$. The gas exchange parameters $P_{n}, g_{s}, C_{i}$ and $T_{r}$ were recorded simultaneously with five seedlings per treatment.

\section{Determination of chlorophyll fluorescence parameters}

Chlorophyll fluorescence was determined via a PAM2000 modulated fluorescence spectrometer (Walz, Germany). After $30 \mathrm{~min}$ of dark adaptation, the minimum fluorescence $\left(F_{\mathrm{o}}\right)$ was obtained by irradiating the measured light $\left(<0.05 \mu \mathrm{mol} \cdot \mathrm{m}^{-2} \cdot \mathrm{s}^{-1}\right)$, and the maximum fluorescence $\left(F_{\mathrm{m}}\right)$ was measured via a saturated pulse light $\left(0.8 \mathrm{~s} ; 8000 \mu \mathrm{mol} \cdot \mathrm{m}^{-2} \cdot \mathrm{s}^{-1}\right)$. The photosynthetic steady-state fluorescence $\left(F_{\mathrm{s}}\right)$ was measured by turning on the actinic light $\left(1 \mathrm{~h} ; 300 \mu \mathrm{mol} \cdot \mathrm{m}^{-2} \cdot \mathrm{s}^{-1}\right)$, the saturated pulse light $\left(8000 \mu \mathrm{mol} \cdot \mathrm{m}^{-2} \cdot \mathrm{s}^{-1}\right)$ was turned on again to obtain the maximum fluorescence $\left(F_{\mathrm{m}}{ }^{\prime}\right)$, the actinic light was turned off, the far-red light was turned on immediately, and the minimum fluorescence $\left(F_{\mathrm{o}}{ }^{\prime}\right)$ under the light was obtained. Other parameters were calculated as follows: the $F_{\mathrm{v}} / F_{\mathrm{m}}=\left(F_{\mathrm{m}}-F_{\mathrm{o}}\right) / \mathrm{F}_{\mathrm{m}}$; the photochemical quantum efficiency of PSII $($ ФPSII $)=\left(F_{\mathrm{m}}{ }^{\prime}-F_{\mathrm{s}}\right) / \mathrm{Fm}^{\prime}$; the photochemical quenching coefficient $(\mathrm{qP})=\left(F_{\mathrm{m}}{ }^{\prime}-F_{\mathrm{s}}\right)$ / $\left(F_{\mathrm{m}}{ }^{\prime}-F_{\mathrm{o}}{ }^{\prime}\right)$; and the non-photochemical quenching $(\mathrm{NPQ})$ coefficient $=\left(F_{\mathrm{m}}-F_{\mathrm{m}}{ }^{\prime}\right) / F_{\mathrm{m}}{ }^{\prime}[45]$.

\section{Measurement of root Lp}

The determination of Lp was performed according to the method of Nardini et al. [58], with slight modifications. The roots of 5 maize seedlings per treatment were cut and removed. The whole roots were then placed in a pressure chamber, the cut was exposed to the outside of the seal ring by approximately a few centimetres, and a gradually increasing pressure (from 0.1 to $0.4 \mathrm{MPa}$ ) was applied to the roots. The sap was collected with preprepared, dried absorbent cotton in Eppendorf tubes at each pressure gradient (for $1 \mathrm{~min}$ ) and then weighed on a precision balance, thereby generating a range of sap flows that represented the whole-plant $\mathrm{T}_{\mathrm{r}}$. The root $\mathrm{Lp}$ was calculated according to the following formula: $\mathrm{Lp}=$ $\mathrm{Jv} / \mathrm{P}$, where $\mathrm{Jv}\left(\mathrm{m} \cdot \mathrm{s}^{-1}\right)$ is the flow rate and $\mathrm{P}(\mathrm{MPa})$ is the external pressure.

\section{RNA extraction and quantitative RT-qPCR}

To extract RNA using a Qiagen RNeasy Plant Mini Kit (Shanghai Baili Biotechnology Co., Ltd., Shanghai, China), $0.1 \mathrm{~g}$ of root and shoot samples was used. The cDNA was then reverse transcribed using an iScript ${ }^{\text {my }}$ cDNA synthesis kit (Bio-Rad, California, USA) kit. The cDNA was diluted 50 -fold, and $2 \mu \mathrm{L}$ was taken for qRTPCR analysis. Actin1 was used as an internal reference gene. A relative quantitative analysis was performed using the $2^{-\triangle \Delta C T}$ method. The primers used are listed in Table S1. Five replicates per treatment and 5 technical replicates per plant were included.

\section{Statistical analysis}

SPSS 19.0 (IBM, Armonk, NY, USA) was used for statistical analysis. The data were subjected to two-way ANOVA with three sources of variation $(\mathrm{NaCl}, \mathrm{DCPTA}$ and their interaction), and the differences between the treatment means within each measured parameter were compared via Duncan's multiple range test $(P<0.05)$ (Additional file 2).

\section{Supplementary information}

Supplementary information accompanies this paper at https://doi.org/10. 1186/s12870-020-02550-W.

Additional file 1: Table S1. List of primer sequences for $q P C R$ analysis. Additional file 2. Research data.

\section{Abbreviations}

$\mathrm{C}_{\mathrm{i}}$ : intracellular $\mathrm{CO}_{2}$ concentration; $\mathrm{Chl}$ a: chlorophyll a; Chl b: chlorophyll b; DCPTA: 2-(3, 4-dichlorophenoxy) triethylamine; DW: dry weight; $F_{0}$ : minimum fluorescence; $F_{\mathrm{m}}$ : maximal fluorescence yield of the dark-adapted state; $F_{\mathrm{v}} /$ $F_{\mathrm{m}}$ : maximal quantum yield of PSII photochemistry; $g_{s}$ : stomatal conductance; JV: sap flow; Lp: root hydraulic conductivity; LRWC: leaf relative water content; NPQ: non-photochemical quenching; $P$ : pressure; $P_{n}$ : net photosynthesis rate; PSII: photosystem II; PPFD: photosynthetic photon flux density; qP: photochemical quenching coefficient; ROS: reactive oxygen species; $T_{r}$ : transpiration rate; $\psi \omega$ : water potential; DPSII: effective quantum yield of PSII photochemistry

\section{Acknowledgements}

We would like to thank American Journal Experts (https://www.aje.cn) for English language editing.

\section{Authors' contributions}

LJL performed the entire experiment and drafted the manuscript. WRG, and SW conceived and designed the experiments. LJL, and SYZ gathered the data and analysed the results. SYZ, CFL, GLZ, CXC and CRQ helped to interpret the results and prepare the manuscript. WRG, SW, ZHW and WHL 
were in charge of manuscript revisions. All authors read and approved the final manuscript.

\section{Funding}

This work was supported by the National Key Research and Development Program of China (2016YFD0300103 and 2017YFD0300506), Heilongjiang Provincial Funding for the National Key R\&D Programs of China (GX18B029), and the "Academic Backbone" Project of Northeast Agricultural University (17XG23). The funding bodies did not involve in the design of the study and collection, analysis, interpretation of data, or writing of the manuscript.

\section{Availability of data and materials}

The datasets used and/or analysed during the current study are available from the corresponding author on reasonable request.

\section{Ethics approval and consent to participate}

Not applicable.

\section{Consent for publication}

Not applicable.

\section{Competing interests}

The authors declare that they have no competing interests.

\section{Author details}

${ }^{1}$ College of Agriculture, Northeast Agricultural University, Harbin 150030, P. R. China. ${ }^{2}$ College of Life Science and Technology, Henan Institute of Science and Technology, Xinxiang 453000, Henan, P. R. China. ${ }^{3}$ Institute of Maize Research, Heilongjiang Academy of Agricultural Sciences, Harbin 150030, P. R. China. ${ }^{4}$ Institute of Crop Science, Chinese Academy of Agricultural Sciences, Beijing, P. R. China.

Received: 9 March 2020 Accepted: 12 July 2020

Published online: 23 July 2020

\section{References}

1. Yadav S, Irfan M, Ahmad A, Hayat S. Causes of salinity and plant manifestations to salt stress: a review. J Environ Biol. 2011;32(5):667-85.

2. Munns R, Gilliham M. Salinity tolerance of crops - what is the cost? New Phytol. 2015;208(3):668-73.

3. Abdel Latef AA, Mostafa MG, Rahman MM, Abdel-Farid AB, Tran LP. Extracts from yeast and carrot roots enhance maize performance under seawaterinduced salt stress by altering physio-biochemical characteristics of stressed plants. J Plant Growth Regul. 2019;38(3):966-79.

4. Munns R, Tester M. Mechanisms of salinity tolerance. Annu Rev Plant Biol. 2008;59(1):651.

5. Abdel Latef AA, Kordrostam M, Zakir A, Zaki H, Saleh OM. Eustress with $\mathrm{H}_{2} \mathrm{O}_{2}$ facilitates plant growth by improving tolerance to salt stress in two wheat cultivars. Plants. 2019;8(9):303.

6. Dagar JC, Sharma PC, Sharma DK, Singh AK. Innovative Saline Agriculture: Springer India. 2016.

7. Wungrampha S, Joshi R, Singla-Pareek SL, Pareek A. Photosynthesis and salinity: are these mutually exclusive? Photosynthetica. 2018;56:1-16.

8. FAO. How to feed the world in 2050. Rome: Food and agriculture organization; 2009.

9. Deinlein U, Stephan AB, Horie T, Luo W, Xu G, Schroeder Jl. Plant salttolerance mechanisms. Trends Plant Sci. 2014:19(6):371-9.

10. Carillo P. GABA shunt in durum wheat. Front Plant Sci. 2018;9:100.

11. Yang Y, Guo Y. Elucidating the molecular mechanisms mediating plant saltstress responses. New Phytol. 2018;217(2):523-39.

12. Ferchichi S, Hessini K, Dell Aversana E, D'Amelia L, Carillo P. Hordeum vulgare and Hordeum maritimum respond to extended salinity stress displaying different temporal accumulation pattern of metabolites. Funct Plant Biol. 2018;45(11):1096-109.

13. Negrão S, Schmöckel SM, Tester M. Evaluating physiological responses of plants to salinity stress. Ann Bot-London. 2017;119(1):1-11.

14. Gururani MA, Venkatesh J, Tran LSP. Regulation of photosynthesis during abiotic stress-induced photoinhibition. Mol Plant. 2015:8(9):1304-20.

15. Sánchez-Blanco MJ, Álvarez S, Ortuño MF, Ruiz-Sánchez MC. Root system response to drought and salinity: root distribution and water transport. Root Engineering Berlin Heidelberg: Springer. 2014:325-52.
16. Munns R. Genes and salt tolerance: bringing them together. New Phytol. 2005;167(3):645-63.

17. Wang $Y$, Wu WH. Potassium transport and signaling in higher plants. Annu Rev Plant Biol. 2013;64(1):451-76.

18. Zhu JK. Regulation of ion homeostasis under salt stress. Curr Opin Plant Biol 2003:6(5):441-5

19. Bassil E, Tajima $\mathrm{H}$, Liang YC, Ohto MA, Blumwald E. The Arabidopsis $\mathrm{Na}^{+} / \mathrm{H}^{+}$ Antiporters $\mathrm{NHX} 1$ and $\mathrm{NHX} 2$ control vacuolar $\mathrm{pH}$ and $\mathrm{K}^{+}$homeostasis to regulate growth, flower development, and reproduction. Plant Cell. 2011; 23(9):3482-97.

20. Assaha DVM, Ueda A, Saneoka H, Alyahyai $R$, Yaish MW. The role of $\mathrm{Na}^{+}$ and $\mathrm{K}^{+}$transporters in salt stress adaptation in glycophytes. Front Physiol. 2017;8:509.

21. Zhang $H$, Wei S, Hu W, Xiao L, Tang M. Arbuscular mycorrhizal fungus rhizophagus irregularis increased potassium content and expression of genes encoding potassium channels in lycium barbarum. Front Plant Sci. 2017:8:440.

22. Gaymard F, Pilot G, Lacombe B, Bouchez D, Bruneau D, Boucherez J, Michauxferrière $\mathrm{N}$, Thibaud JB, Sentenac $\mathrm{H}$. Identification and disruption of a plant shaker-like outward channel involved in $\mathrm{K}^{+}$release into the xylem sap. Cell. 1998;94(5):647-55.

23. Yakhin OI, Lubyanov AA, Yakhin IA, Brown PH. Biostimulants in plant science: a global perspective. Front Plant Sci. 2016;7:12684.

24. Yokoyama H, Hayman EP, Hsu WJ, Poling SM, Bauman AJ. Chemical bioinduction of rubber in guayule plant. Science. 1977;197(4308):1076-8.

25. Keithly $\mathrm{JH}$, Yokoyama $\mathrm{H}$, Gausman $\mathrm{H}$. Enhanced yield of tomato in response to 2-(3,4-dichlorophenoxy) triethylamine (DCPTA). Plant Growth Regul. 1990; 9(2):127-36

26. Keithly $\mathrm{JH}$, Yokoyama $\mathrm{H}$. Effects of 2-(3,4-dichlorophenoxy) triethylamine (DCPTA) upon the growth and development of radish (Raphanus sativus L.) Abstracts of Papers of the American Chemical Society. 1986;192(3):44.

27. Wang $L$, Zhang $P$, Wang RN, Wang $P$, Huang SB. Effects of variety and chemical regulators on cold tolerance during maize germination. J Integr Agr. 2018;17:2662-9.

28. Keithly HH, Yokoyama H, Gausman HW. Effect of 2-(3,4-dichlorophenoxy) triethylamine (DCPTA) on the growth and development of sugarbeet. Plant Sci. 1990;68(1):57-64

29. Wan JH, Mendoza K. Effect of 2-(3,4-dichlorophenoxy) triethylamine on guayule (Parthenium argentatum) cell suspension cultures. J Agr Food Chem. 1992:40(5):924-6.

30. Benedict CR, Rosenfield CL, Mahan JR, Madhavan S, Yokoyama H. The chemical regulation of carotenoid biosynthesis in citrus. Plant Sci. 1985; 41(3):169-73.

31. Gu WR, Li ZH, Zhai ZX. Regulation of tertiary amine bioregulator on photosynthesis and chlorophyll fluorescence parameters of corn leaves. Acta Agric Boreali-Sin. 2008;23(3):85-9.

32. Davis TD, Sankhla N, Smith BN. Influence of 2-(3,4 dichlorophenoxy)triethylamine on photosynthesis of Phaseolus vulgaris L. Photosynth Res. 1986;8(3):275-81.

33. Yuan LD, Gu WR, Sun J, Wang YC, Li J, Wei S. Regulation of DCPTA treatment on chlorophyll content and fluorescence parameters of maize seedlings leaves under low-temperature stress. Crops. 2012;5:63-7.

34. Zhang H, Gu WR, Wang YC, Li LJ, Zeng FX, Yang ZF, Yang DG, Wei S. Effects of DCPTA on root growth, osmotic adjustment and cell membrane permeability of maize seedlings under salt stress. Chinese J Ecol. 2015;34(9): 2474-81.

35. Xie TL, Gu WR, Meng Y, Li J, Li LJ, Wang YC, Qu DY, Wei S. Exogenous DCPTA ameliorates simulated drought conditions by improving the growth and photosynthetic capacity of maize seedlings. Sci Rep. 2017;7(1):12684.

36. Zhu HG, Gu WR, Wang YC, Jiang ZZ, Xie TL, Li J, Wei S. Effects of DCPTA on the physiological and biochemical characteristics in maize seedling leaves under low temperature stress. J Nucl Agric Sci. 2015;29(3):549-56.

37. Nuss ET, Tanumihardjo SA. Maize: a paramount staple crop in the context of global nutrition. Compr Rev Food Sci F. 2010:9(4):417-36.

38. Zhang J, Yu H, Zhang Y, Wang Y, Li M, Zhang J, Duan L, Zhang M, Li Z. Increased abscisic acid levels in transgenic maize overexpressing AtLOS5 mediated root ion fluxes and leaf water status under salt stress. J Exp Bot. 2016:67(5):1339-55.

39. Neves-Piestun BG, Bernstein N. Salinity-induced changes in the nutritional status of expanding cells may impact leaf growth inhibition in maize. Funct Plant Biol. 2005;32(2):141-52. 
40. Farooq M, Hussain M, Wakeel A, Siddique KHM. Salt stress in maize: effects, resistance mechanisms, and management. A review. Agron Sustain Dev. 2015;35(2):461-81.

41. Flowers TJ, Flowers SA. Why does salinity pose such a difficult problem for plant breeders? Agr Water Manage. 2005;78(1):15-24.

42. Zhang M, Cao Y, Wang Z, Wang ZQ, Shi J, Liang X, Song W, Chen Q, Lai J, Jiang C. A retrotransposon in an HKT1 family sodium transporter causes variation of leaf $\mathrm{Na}^{+}$exclusion and salt tolerance in maize. New Phytol. 2017;217(3):1161-76

43. Li XY. Regulation of DCPTA on soybean seedling growth under drought stress. Soybean Sci. 2016;36:86-90.

44. Farquhar GD, Sharkey TD. Stomatal conductance and photosynthesis. Plant Physiol. 1982;33(1):317-45.

45. Baker NR. Chlorophyll fluorescence: a probe of photosynthesis in vivo. Annu Rev Plant Biol. 2008:59(1):89-113.

46. Pinhero RG, Rao MV, Paliyath G, Murr DP, Fletcher RA. Changes in activities of antioxidant enzymes and their relationship to genetic and paclobutrazolinduced chilling tolerance of maize seedlings. Plant Physiol. 1997;114(2): 695-704.

47. Hamed KB, Ellouzi H, Talbi OZ, Hessini K, Slama I, Ghnaya T, Bosch SM, Savouré A, Abdelly C. Physiological response of halophytes to multiple stresses. Funct Plant Biol. 2013:40:883-96.

48. Ji HT, Pardo JM, Batelli G, Van Oosten MJ, Bressan RA. The salt overly sensitive (SOS) pathway: established and emerging roles. Mol Plant. 2013; 6(2):275-86

49. Che J, Zhang $H Q$, Zhang $X L$, Tang M. Arbuscular mycorrhizal symbiosis alleviates salt stress in black locust through improved photosynthesis, water status, and $\mathrm{K}^{+} / \mathrm{Na}^{+}$homeostasis. Front Plant Sci. 2017:8:1739.

50. Pandolfi C, Azzarello E, Mancuso S, Shabala S. Acclimation improves salt stress tolerance in Zea mays plants. J Plant Physiol. 2016;201:1-8.

51. Zhang HX, Hodson JN, Williams JP, Blumwald E. Engineering salt-tolerant Brassica plants: characterization of yield and seed oil quality in transgenic plants with increased vacuolar sodium accumulation. P Natl Acad Sci USA 2001;98(22):12832-6

52. Jiang C, Zheng Q, Liu Z, Xu W, Liu L, Zhao G, Long X. Overexpression of Arabidopsis thaliana $\mathrm{Na}^{+} / \mathrm{H}^{+}$antiporter gene enhanced. Trees. 2012;26(3): 685-94.

53. Zhang HX, Blumwald E. Transgenic salt-tolerant tomato plants accumulate salt in foliage but not in fruit. Nat Biotechnol. 2001:19(8):765-8.

54. Pitann B, Mohamed AK, Neubert AB, Schubert S. Tonoplast $\mathrm{Na}^{+} / \mathrm{H}^{+}$ antiporters of newly developed maize (Zea mays) hybrids contribute to salt resistance during the second phase of salt stress. J Plant Nutr Soil Sci. 2013; 176(2):148-56.

55. Cui TA, Tian Y, Betts SA, Chalmandrier R, Shabala S. Ionic relations and osmotic adjustment in durum and bread wheat under saline conditions. Funct Plant Biol. 2009;36(12):1110-9.

56. Maathuis FJ. The role of monovalent cation transporters in plant responses to salinity. J Exp Bot. 2006:57(5):1137-47.

57. Arnon DI. Copper enzymes in isolated chloroplasts: polyphenoloxidase. Beta vulgaris. Plant Physiol. 1949;24(1):1-15.

58. Trubat R, Cortina J, Vilagrosa A. Root architecture and hydraulic conductance in nutrient deprived Pistacia lentiscus L. seedlings. Oecologia. 2012;170(4):899-908

\section{Publisher's Note}

Springer Nature remains neutral with regard to jurisdictional claims in published maps and institutional affiliations.

Ready to submit your research? Choose BMC and benefit from:

- fast, convenient online submission

- thorough peer review by experienced researchers in your field

- rapid publication on acceptance

- support for research data, including large and complex data types

- gold Open Access which fosters wider collaboration and increased citations

- maximum visibility for your research: over $100 \mathrm{M}$ website views per year

At $\mathrm{BMC}$, research is always in progress.

Learn more biomedcentral.com/submissions 